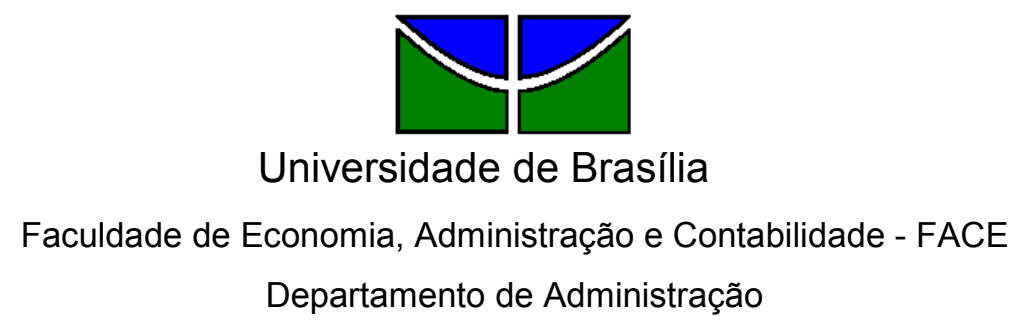

Departamento de Administração

ISABELA COELHO FERREIRA

\title{
O ENVOLVIMENTO DO CONSUMIDOR INFANTIL: Uma pesquisa comparativa entre crianças de escolas públicas e privadas de Brasília
}

Brasília - DF 


\section{ISABELA COELHO FERREIRA}

\section{O ENVOLVIMENTO DO CONSUMIDOR INFANTIL: Uma pesquisa comparativa entre crianças de escolas públicas e privadas de Brasília}

Monografia apresentada ao

Departamento de Administração como requisito parcial à obtenção do título de Bacharel em Administração.

Professora Orientadora: Késia Rozzett Oliveira 
Ferreira, Isabela Coelho.

O envolvimento do consumidor infantil: uma pesquisa comparativa entre crianças de escolas públicas e privadas de Brasília / Isabela Coelho Ferreira. - Brasília, 2010.

$78 \mathrm{f}$. : il.

Monografia (bacharelado) - Universidade de Brasília, Departamento de Administração, 2010.

Orientadora: Bel. Késia Rozzett Oliveira, Departamento de Administração.

1. Envolvimento do consumidor. 2. Marketing infantil. 3. Escolas públicas e privadas I. Título 


\title{
ISABELA COELHO FERREIRA
}

\section{O ENVOLVIMENTO DO CONSUMIDOR INFANTIL: uma pesquisa comparativa entre crianças de escolas públicas e privadas de Brasília}

\begin{abstract}
A Comissão Examinadora, abaixo identificada, aprova o Trabalho de Conclusão do Curso de Administração da Universidade de Brasília da aluna
\end{abstract}

\section{Isabela Coelho Ferreira}

Professora Késia Rozzett Oliveira Professora-Orientadora

Prof. MSc Walter Eustáquio Ribeiro

Professor-Examinador
Profa $^{a}$. Dr ${ }^{\text {a }}$. Gisela Demo Fiuza

Professora-Examinadora 
Aos meus pais, tão fundamentais em todas as minhas conquistas e realizações. Por estarem sempre presentes, mesmo quando a distância existe. Sem vocês nada disso seria possível! 


\section{AGRADECIMENTOS}

A Deus, pela vida que me concedeu!

À professora Késia Rozzett, tão querida e prestativa, por ser tudo e muito mais do que eu poderia pedir como orientadora. Obrigada por dividir comigo seus conhecimentos, seu tempo e paixão pela vida acadêmica, por me fazer buscar sempre o melhor e contribuir para o meu crescimento. As palavras não são suficientes para expressar minha gratidão e dizer o quanto sua orientação foi especial! Você é realmente abençoada!

Às escolas que permitiram a aplicação dos questionários, aos professores que concederam minutos preciosos de suas aulas e principalmente às crianças que participaram da pesquisa.

À professora Maria de Fátima Bruno de Faria, por aulas maravilhosas que tornaram a realização da monografia mais leve, fazendo deste um momento de grande alegria e satisfação.

À minha mãe, responsável por tudo de melhor que existe em mim, por todos os ensinamentos, pela dedicação explícita a mim e aos meus irmãos, pelo amor e carinho, por ser a minha fortaleza. Te amo!

Ao meu pai, meu grande exemplo de determinação, pela amizade e amor incondicionais, por nunca deixar de acreditar no meu potencial e ser sempre o meu maior incentivador. Tenho imenso orgulho de ser sua filha, amo você quiído!

Aos meus irmãos, por cuidarem de mim e serem tão fundamentais na minha vida!

Ao meu namorado, Rafael, pela paciência durante a realização deste trabalho, pelo livro que inspirou toda esta pesquisa e principalmente pelo companheirismo e carinho sempre tão necessários. Obrigada também à sua família querida, adoro vocês!

Aos amigos que estiveram comigo nestes quase 5 anos de faculdade e dividiram momentos tão especiais que tornaram estes anos inesquecíveis.

Aos amigos de escola, os de infância e os do trabalho, que de maneira direta ou indireta contribuíram para que eu chegasse até aqui!

À Universidade de Brasília, por investir seus recursos na minha formação.

A todos meu muito obrigada! 
"O que se faz agora com as crianças é o que elas farão depois com a sociedade." Karl Mannheim 


\section{RESUMO}

As crianças hoje são reconhecidamente um grande público consumidor. Quando não realizam suas compras sozinhas estão influenciando as compras de seus pais, familiares e amigos. Assim, o público infantil está sempre informado sobre os últimos lançamentos, novas tecnologias e marcas. Ao buscar conhecer mais sobre esse segmento, este trabalho teve como objetivo comparar as diferenças entre o envolvimento do consumidor infantil em crianças de escolas públicas e privadas de Brasília. $O$ fator envolvimento do consumidor definido no instrumento utilizado foi medido por meio de três subfatores, sendo eles: insatisfação, orientação do consumidor e reconhecimento da marca. A natureza da pesquisa foi quantitativa, por meio da técnica de levantamento de dados, survey, fazendo uso do questionário como instrumento. Foi realizada pesquisa censitária com alunos de seis escolas públicas e duas escolas privadas de Brasília, obtendo-se 1.229 questionários, sendo 1.149 considerados válidos após a limpeza dos dados. A medida descritiva utilizada para análise dos dados foi a média, além das freqüências de resposta. Além disso, foi realizada uma análise inferencial por meio da Análise de Variância (ANOVA). Os resultados obtidos indicam que as crianças, independente das escolas em que estudam, são consumistas e aquelas que estudam em escolas públicas possuem um maior envolvimento do consumidor, comprovado em 10 dos 16 itens presentes no questionário. Os objetivos propostos nesta pesquisa foram alcançados e sugerese que para pesquisas futuras uma abordagem mista seja utilizada em virtude da riqueza de detalhes que o instrumento qualitativo aliado ao quantitativo tem a oferecer.

$\begin{array}{llll}\text { Palavras-chave: } & \begin{array}{l}\text { 1. Envolvimento } \\ \text { do consumidor. }\end{array} & \begin{array}{l}\text { 2. Marketing } \\ \text { Infantil. }\end{array} & \begin{array}{l}\text { 3. Escolas públicas e } \\ \text { privadas. }\end{array}\end{array}$




\section{LISTA DE GRÁFICOS}

Gráfico 1 - Estado civil dos pais de crianças de escolas privadas.......................44

Gráfico 2 - Estado civil dos pais de crianças de escolas públicas .........................45

Gráfico 3 - Freqüência de respostas do item IN1 .............................................47

Gráfico 4 - Freqüência de respostas do item IN3 .........................................48

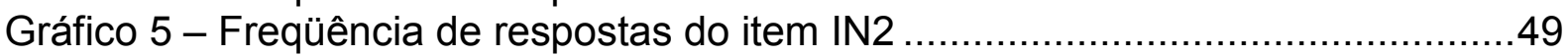

Gráfico 6 - Freqüência de respostas do item IN4 .........................................50

Gráfico 7 - Freqüência de respostas do item IN5 ........................................ 51

Gráfico 8 - Freqüência de respostas do item IN6 .......................................... 52

Gráfico 9 - Freqüência de respostas do item $\mathrm{OC1}$...........................................54

Gráfico 10 - Freqüência de respostas do item OC2 ….................................55

Gráfico 11 - Freqüência de respostas do item OC3 …......................................56

Gráfico 12 - Frequência de respostas do item OC4 …........................................57

Gráfico 13 - Freqüência de respostas do item OC5 ….......................................58

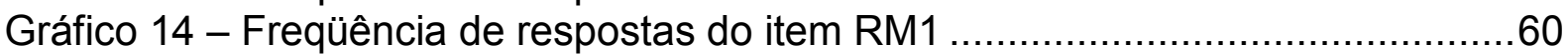

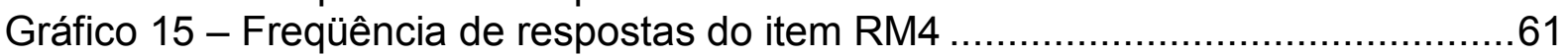

Gráfico 16 - Freqüência de respostas do item RM2 ......................................62

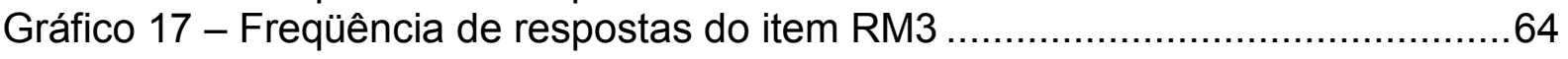

Gráfico 18 - Freqüência de respostas do item RM5 .......................................65

\section{LISTA DE QUADROS}

Quadro 1 - Itens do fator Insatisfação .......................................................46

Quadro 2 - Itens do fator Orientação do Consumidor.......................................... 52

Quadro 3 - Itens do fator Reconhecimento da Marca........................................59 


\section{LISTA DE TABELAS}

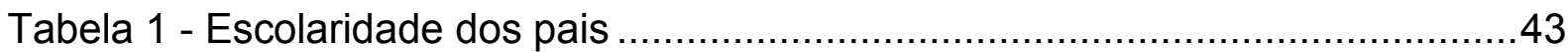

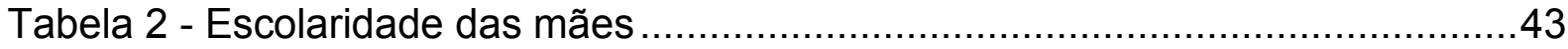

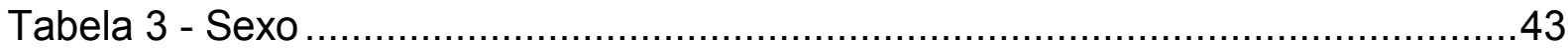

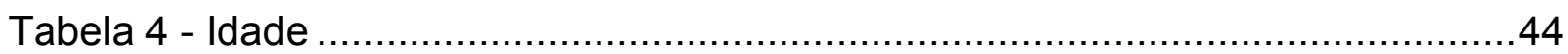

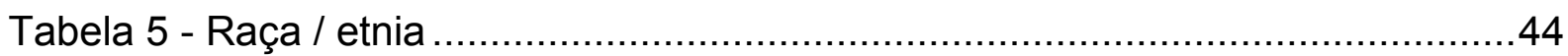

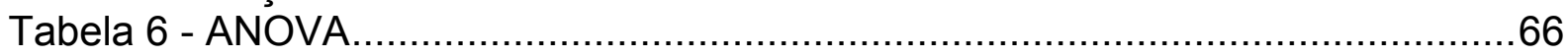




\section{SUMÁRIO}

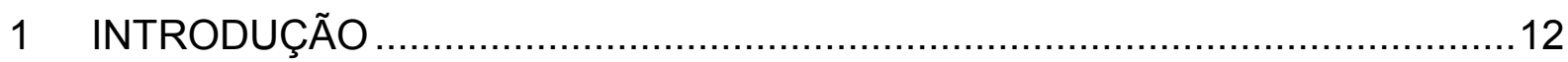

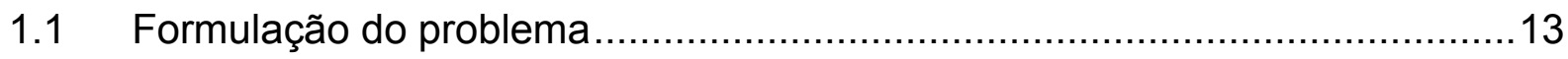

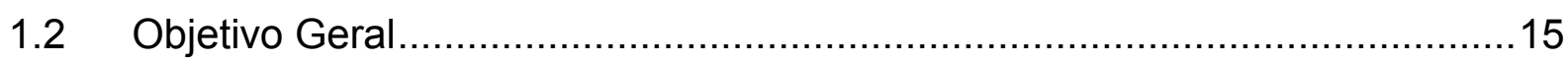

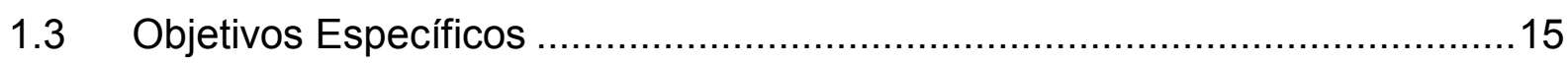

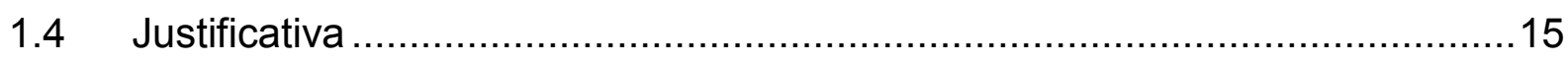

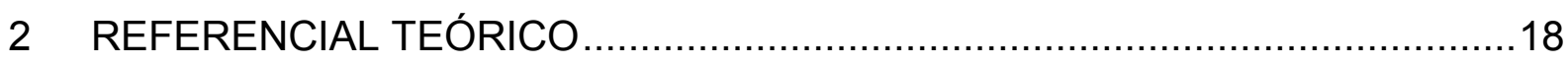

2.1 Marketing e a segmentação de mercado....................................................18

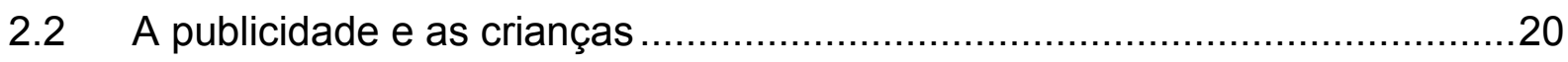

2.2.1 Compradoras e influenciadoras das compras ......................................24

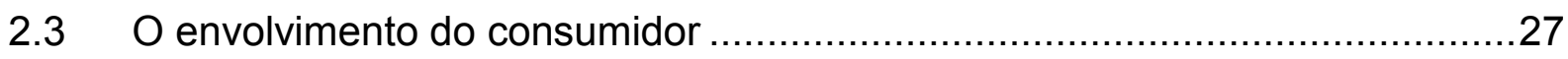

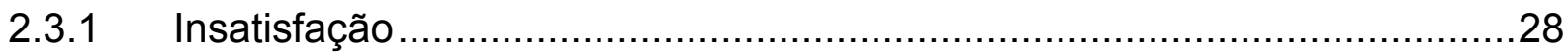

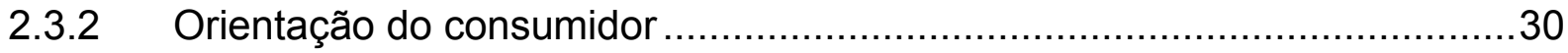

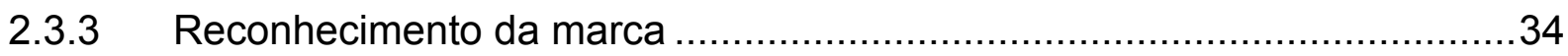

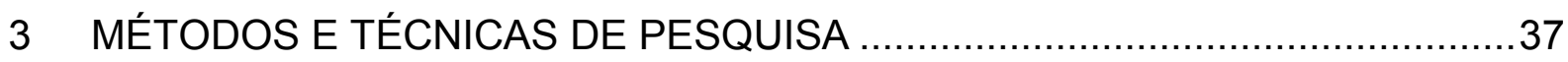

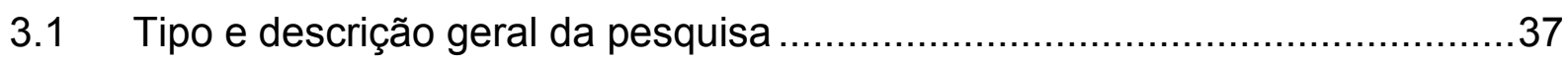

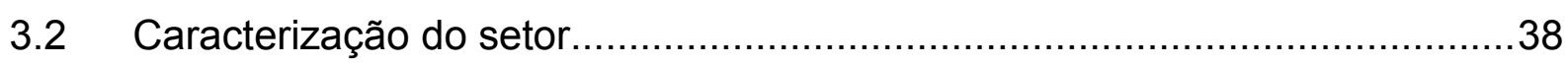

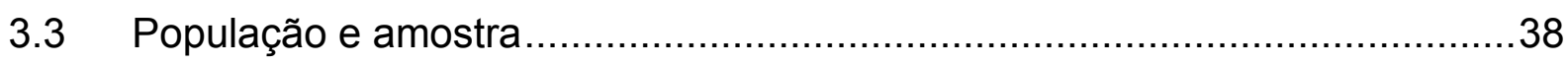

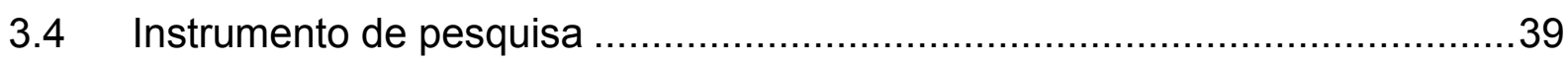

3.5 Procedimentos de coleta e de análise de dados .........................................40

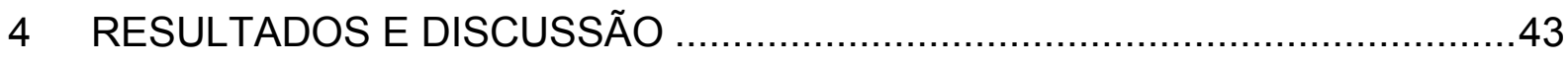

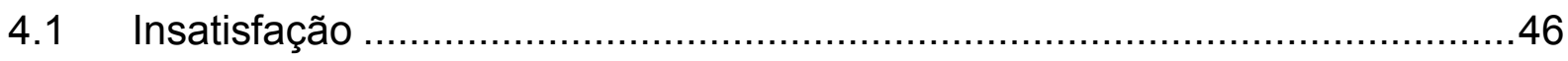

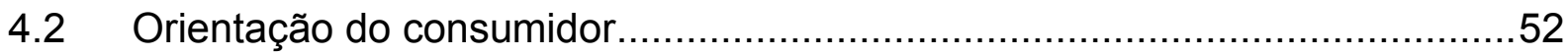

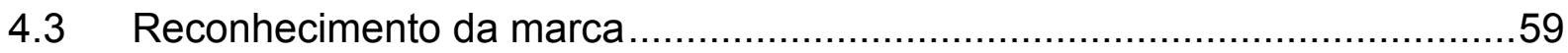

5 CONCLUSÕES E RECOMENDAÇÕES ……….......................................6

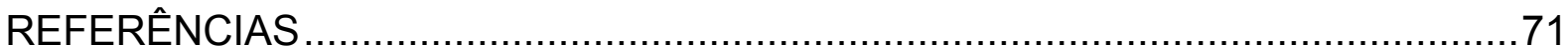




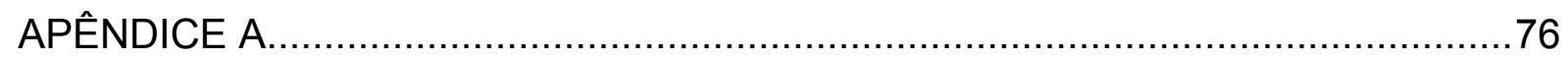

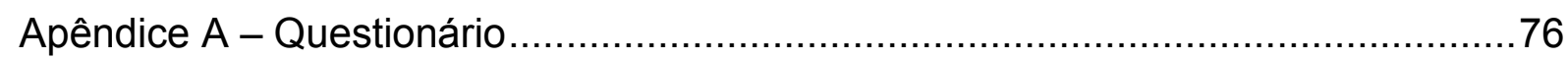




\section{INTRODUÇÃO}

O impacto causado pelo marketing na vida das crianças é um dos temas de grande importância na atualidade. A cada dia, o acesso e a exposição das crianças aos diversos tipos de informações fornecidas pela mídia crescem e os resultados provocados por essa constante exposição aos meios de comunicação precisam ser investigados. É importante que se destaque a necessidade de se conhecer quão imersas as crianças se encontram na cultura do consumo, para que os pais, responsáveis e o próprio governo possam tomar as devidas providências.

Para Kotler e Keller (2006a) o marketing é um processo social por meio do qual pessoas e grupos de pessoas obtêm aquilo de que necessitam e o que desejam com a criação, oferta e livre negociação de produtos e serviços de valor com outros. Para Cobra (1992a, p. 29), o marketing vai além da compreensão do mercado e oferta de produtos e serviços, ele deve ser "um compromisso com a busca da melhoria da qualidade de vida das pessoas...". Richers (2000, p. 5) define marketing como a "intenção de entender e atender o mercado", justificando assim a necessidade de compreensão do consumidor, descobrindo o que ele anseia para em seguida buscar satisfazer seus desejos.

Exatamente por buscar traduzir as necessidades e vontades das pessoas em produtos e serviços, o marketing precisa desenvolver-se pautado em princípios e atitudes éticas e responsáveis, pois ele oferece mais do que bens materiais, oferece promessas de sonhos e uma vida diferenciada.

O termo marketing infantil é utilizado para se referir ao marketing de produtos e serviços destinados a este público específico. Segundo Kotler e Keller (2006b), o comportamento de compra dos consumidores é influenciado por fatores culturais, como a cultura, subcultura e classes sociais; sociais, como grupos de referência, família, status e papéis sociais; pessoais, como idade, ocupação, personalidade, estilo de vida e valores; e psicológicos, como a percepção e a aprendizagem. No ambiente familiar, o público infantil tornou-se notoriamente influenciador das compras e os profissionais de marketing estão atentos para as mudanças ocorridas 
nos padrões de compra da sociedade, aproveitando as oportunidades que surgem para fortalecerem suas marcas.

Segundo o estudo Kids Power - Poder das crianças (2007) realizado pelo instituto de pesquisa TNS InterScience o ambiente em que vivem as crianças, atualmente, é muito diferente que aquele vivenciado anos atrás. No âmbito familiar, os pais encontram dificuldades de impor limites; as familías passaram a ser menores e houve uma flexibilização dos controles, onde existe um maior diálogo entre pais e filhos e uma diminuição do castigo.

O Kids Power - Poder das crianças (2007) também lembra que com relação à tecnologia, os pequenos sofrem o impacto de muitas imagens desde cedo, existe uma grande exposição a informações (de todos os tipos) e diversas tecnologias; ocorre uma difusão massiva de mundos fantásticos ao mesmo tempo em que se proporciona à criança "lidar" com temas de adultos, podendo ocorrer uma distorção da realidade.

No que diz respeito ao mercado, de acordo com o Kids Power - Poder das crianças (2007), existe uma grande oferta de produtos voltados a este público, houve uma ampliação do mundo do prazer, e por terem conhecimento sobre diversos temas, há o reconhecimento e o desejo por produtos de categorias destinadas a outros segmentos da população. Todas estas mudanças fizeram com que houvesse uma diluição das fronteiras entre o mundo infantil, adolescente e adulto; houve um fortalecimento do egocentrismo e uma menor tolerância a frustração por parte destas crianças.

A valorização deste público e o crescente investimento sobre ele justificam a maior atenção que passa a ser dedicada às crianças pelo mercado, elas tornaram-se grandes consumidoras.

\subsection{Formulação do problema}

Hoje as pessoas vivem na Era da Informação. Notícias que antes demoravam horas para serem transmitidas para diversos locais do mundo são anunciadas, vistas e lidas em uma questão de segundos por milhares de pessoas. O conhecimento 
humano para lidar com diferentes máquinas e tecnologias cresce a cada momento e, assim, os indivíduos desde pequenos vão aprendendo a lidar com um número maior de dados, informações e aparelhos eletrônicos. O computador, o rádio e a televisão são manuseados por crianças cada vez menores que demonstram grande habilidade em lidar com a tecnologia e que enxergam estes objetos como indispensáveis à vida cotidiana.

Preocupações que há décadas não existiam, hoje passam a ser discutidas freqüentemente e com certa urgência, pois as mudanças não param e o mundo se desenvolve sempre em maior velocidade. Com o advento das tecnologias, a exposição de crianças aos diferentes tipos de informação produzidos pela mídia tornou-se crescente e a reformulação da estrutura familiar fez com que os pais passassem a dedicar menos tempo aos cuidados dos filhos e na presença deles, fazendo com que estas crianças ficassem mais tempo sozinhas, em creches e escolas, ou aos cuidados de terceiros. O entretenimento passou de jogos ao ar livre e brincadeiras com outras crianças a jogos de computador e vídeo game, brincadeiras com os irmãos dentro de casa e ao aumento de horas diante da televisão. Essas mudanças na vida cotidiana fizeram surgir novas situações, novos comportamentos e novas atitudes, tanto por parte dos pais quanto por parte dos filhos.

As crianças passaram a ser tratadas pelas empresas como consumidoras, aumentou-se o investimento destinado a esse público e em conseqüência aumentaram os produtos e propagandas orientados a eles. As crianças continuam a ser crianças, mas as grandes corporações já enxergam nelas as influenciadoras da compra de hoje e as consumidoras adultas do amanhã, por isso acreditam que é importante o quanto antes fidelizá-las.

Para Page e Ridgway (2001), o ambiente em que as crianças consomem tem profunda influência nos seus padrões de consumo, o que explica a existência de diferenças nos padrões de consumo entre crianças que vivem em áreas socioeconômicas diferentes, padrões que potencialmente podem persistir durante a vida do consumidor já adulto. Contudo, as autoras afirmam que as dissimilaridades existentes nos padrões de consumo não implicam necessariamente que crianças de uma determinada classe socioeconômica sejam mais ou menos consumistas do que o restante das crianças de outra classe. 
Mayo (2005) realizou pesquisa com jovens do Reino Unido com idades entre 10 e 19 anos e verificou que aqueles que possuem menos, de classes socioeconômicas inferiores $C$ e D, são mais interessados no consumo e preocupações materialistas. Para o autor, essa "lacuna de aspiração" está mais marcada em lares mais pobres.

Assim, neste trabalho, utiliza-se a hipótese de que existam diferenças no envolvimento do consumidor entre crianças de famílias com rendas variadas, acreditando-se que as crianças de classes inferiores sejam mais consumistas do que as crianças de outras classes. Para que isso seja verificado a situação foi problematizada e questiona-se: existem diferenças no envolvimento do consumidor infantil de crianças de escolas públicas e privadas de Brasília?

\subsection{Objetivo Geral}

Comparar as diferenças entre o envolvimento do consumidor infantil em crianças de escolas públicas e privadas de Brasília.

\subsection{Objetivos Específicos}

- Analisar o envolvimento do consumidor infantil em crianças de escolas públicas;

- Analisar o envolvimento do consumidor infantil em crianças de escolas privadas;

- Traçar o perfil demográfico da população pesquisada.

\subsection{Justificativa}

Com o passar dos anos, as crianças tornaram-se um público alvo interessante para as empresas. Elas consomem produtos infantis e possuem um razoável poder de 
decisão. Geralmente, são influenciadoras de compras na família e obviamente irão crescer e se tornarão adolescentes e adultos consumidores (daí a importância vista pelas empresas de fidelizá-las ainda pequenas) além de exercerem influência entre seus pares nos diferentes ambientes de convivência como escolas, clubes e cursos.

Elas assistem televisão como forma de entretenimento e ficam expostas não só à publicidade direcionada às crianças, mas também à publicidade direcionada aos adultos e assim acabam seduzidas por marcas que não são destinadas ao público infantil, o que pode resultar na adoção de comportamentos que não são condizentes à realidade delas próprias.

O número de estudos que retratam a relação do marketing com as crianças é crescente (CHILDS; MAHER, 2003; O'SULLIVAN, 2005; PAINE; STEWART; KRUGER, 2002). No Brasil, o Instituto Alana e a Agência de Notícias dos Direitos da Infância (ANDI) buscam divulgar a necessidade do controle e atenção com o marketing destinado ao público infanto-juvenil, destacando o aumento da obesidade no país como um dos fatores que deveriam fazer as autoridades e a população atentarem para este marketing e aquilo a que ele se propõe e principalmente o modo como os produtos são oferecidos.

Segundo Linn (2006), Diretora Associada do Centro de Mídia Infantil Judge Bakere e co-fundadora da Coalizão pelo Fim da Exploração Comercial Infantil, o investimento mundial no marketing direcionado ao público infantil está estimado em cerca de US\$ 15 bilhões anuais. Trata-se de uma estratégia de adultos onde os alvos são as crianças. O marketing infantil recebe enormes investimentos, é explorado em inúmeras pesquisas que buscam cada vez mais entender como entrar nos desejos infantis, descobrir o que as crianças almejam e com o que sonham de forma a tornar tudo realidade, uma realidade que poderá ser consumida à exaustão de pais e dos próprios filhos.

Nesta batalha travada pelo marketing infantil, faz-se uso de todas as armas. Psicólogos treinados e bem orientados sobre a formação infantil trabalham em favor das grandes corporações, revelando como chegar mais próximo dos sonhos e desejos mais íntimos e profundos das crianças. É notável a grande mobilização da indústria, que muitas vezes age por meio de uma ética distorcida e, no entanto, a população em geral - e aqui foca-se principalmente nos adultos - não se mobilizam de forma firme para evitar as grandes perdas que a infância tem sofrido. 
Rezende e Rezende (1993, p. 4) afirmam que as crianças brasileiras assistem em média 4 horas de televisão diariamente, um tempo quase igual àquele que dedicam à escola. Só este fato já deveria gerar preocupação para os responsáveis e "o consumo infantil, geralmente acrítico e passivo, sem dúvida terá decisiva interferência na representação que a criança formará da realidade".

Além do mais, para Schor (2004), a literatura sobre as crianças e sua relação com o consumo é bastante limitada, diferenciando então as crianças dos adolescentes, que para a autora são muito estudados.

Uma vez que no país existem poucos trabalhos publicados sobre o tema, este estudo busca contribuir para o aumento da produção científica nacional sobre a relação do público infantil com o consumo, um assunto extremamente atual e de impactos na vida da sociedade como um todo.

O tempo foi um fator limitante na escolha do local de pesquisa. Optou-se por se trabalhar no ambiente escolar uma vez que este ambiente permite o rápido acesso a uma grande quantidade de crianças, possibilitando a abordagem de um maior número de indivíduos, facilitando a realização da pesquisa. 


\section{REFERENCIAL TEÓRICO}

Neste capítulo, será abordada a fundamentação teórica do trabalho realizado. Ela abrange o estudo sobre a segmentação de mercado, o relacionamento da criança com o marketing e o envolvimento do consumidor infantil.

\subsection{Marketing e a segmentação de mercado}

Para Grossi e Santos (2007), a sociedade do consumo teve início com a Revolução Industrial no final do século XVIII, tendo seu alicerce no capitalismo. Segundo Pietrocolla (1989 apud GROSSI; SANTOS, 2007) com a quebra da Bolsa de Nova York, em 1929, os países periféricos precisaram buscar alternativas para suprir a necessidades de produtos industrializados que não eram mais acessíveis, e para tanto precisaram desenvolver uma política voltada para a industrialização, o que acarretou no crescimento de indústrias, ainda que pequenas, responsáveis pela produção de bens de consumo essenciais para a sobrevivência.

Pinho (2001) argumenta que, justamente por ocorrer um aumento da capacidade de produção na década de 1930 , em alguns setores, a produção veio a superar a demanda. Com a criação de um maior número de indústrias os monopólios passaram a sofrer concorrência de seus competidores e conseqüentemente tiveram que desenvolver estratégias mais eficazes de vendas e promoção. Neste sentido, a produção passou a ser orientada para as vendas. Até este momento "o consumo continuava um fator relegado a segundo plano, pois não se reconhecia que a demanda de um produto pudesse ser criada ou estimulada" (PINHO, 2001, p. 21).

Pietrocolla (1989 apud GROSSI; SANTOS, 2007) afirma que o desenvolvimento da economia promoveu o crescimento dos países periféricos, os quais após alguns anos, com o aumento da qualidade de vida de suas populações, passaram a copiar os hábitos de consumo dos países centrais. Para o autor estes países centrais já se desenvolviam pautados em uma sociedade do consumo, onde a lógica vigente 
inventa novas necessidades que são traduzidas na criação de novos bens que possam ser consumidos, o que faz girar uma roda que não pára.

De acordo com Pinho (2001), o termo marketing começou a ser utilizado nos Estados Unidos no início do século XX. Em 1930 foi fundada a American Marketing Assossiation (AMA), organização responsável por reunir os profissionais que se dedicam à atividade. No Brasil, o marketing foi introduzido pelas multinacionais européias e norte-americanas por volta de 1950, e justamente nesta época o conceito de marketing começa a organizar-se na orientação para o mercado, onde entende-se a necessidade de conhecer a fundo o consumidor para produção dos bens e serviços.

Atualmente, com mercados altamente saturados, para competir com mais eficácia muitas empresas optam por concentrar seus esforços, ações e pesquisas em determinados público-alvo, segmentando a população.

Para Kotler e Keller (2006c, p. 237), "um segmento de mercado consiste em um grande grupo de consumidores que possuem as mesmas preferências." A proliferação de meios de propaganda e canais de distribuição além da fragmentação crescente do mercado são alguns dos fatores que tornaram o marketing de massa ultrapassado, tornando-o muito caro e dificultando sua existência. Neste contexto a segmentação de mercado surge como alternativa para a obtenção de maior satisfação do público-alvo. Rocha e Christensen (1987, p. 48) definem que "segmentar um mercado é reconhecer sua natureza essencialmente heterogênea.", ou seja, se as pessoas são diferentes, se suas preferências são diversas, de maneira a ser mais eficaz o marketing precisa focar-se em determinado grupo que apresente características similares e preferências parecidas e a forma para se obter isso é a partir da segmentação do mercado. A identificação destes compradores com comportamentos de compra homogêneos é o grande desafio da segmentação de mercado segundo Cobra (1992b).

Consoante com os demais autores Las Casas (1997) afirma que a

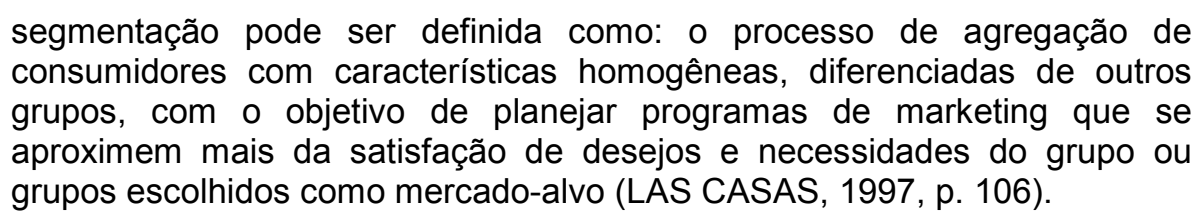


Cobra (1992b, p. 279) cita alguns requisitos para a segmentação do mercado, tais como "a necessidade de um segmento ser especificamente identificado e medido, evidenciar um potencial adequado, ser economicamente acessível, reagir aos esforços de marketing e finalmente ele precisa ser estável". Para que ocorra a segmentação de mercado é necessário que se conheça a fundo o público-alvo da ação de marketing. Este processo permite que sejam oferecidos ao público produtos e serviços que correspondam aos seus desejos. Neste contexto o público infantil é considerado de extrema importância, uma vez que além de exercerem o papel de influenciadores nas compras familiares são também os futuros compradores do amanhã.

Dois grupos gerais de variáveis são utilizados para segmentar os mercados consumidores para Kotler e Keller (2006c, p. 243). Alguns pesquisadores levam em consideração características geográficas, demográficas e psicográficas das pessoas. Outros buscam a identificação dos segmentos por meio da observação de questões comportamentais, como "as respostas dos consumidores aos benefícios procurados, ocasiões e uso ou marcas".

Uma vez que o público infantil não é homogêneo a segmentação também se faz necessária para o desenvolvimento de ações mais eficazes. As variáveis demográficas como sexo, idade e renda familiar são algumas que permitem estruturar grupos mais específicos e de características mais similares principalmente quando se trata deste público em particular (KOTLER; KELLER, 2006c).

Na próxima seção, será abordada a relação que se estabelece entre as crianças e a publicidade destinada à elas.

\subsection{A publicidade e as crianças}

Segundo Strasburger (2004), as crianças gastam um enorme tempo com a mídia. Mais tempo do que eles gastam com qualquer outra atividade de lazer, com exceção de dormir. Quando as crianças de hoje chegarem aos 70 anos elas terão gasto de 7 a 10 anos de suas vidas assistindo somente televisão. Para o autor, as crianças estão mais sujeitas a sofrer influência da mídia, por diversos motivos: por terem 
menos experiências com situações da vida real e por conseqüência serem mais ingênuas; por estarem mais dispostas a acreditar nas informações que recebem da mídia, uma vez que possuem um pensamento crítico pouco desenvolvido e por acreditarem que a mídia está representando o mundo real. Assim, quanto mais assistem televisão mais eles esperam que suas vidas aconteçam em conformidade com as regras e comportamentos que eles assistem de modelo na TV. Para Strasburger (2004) a televisão e outras mídias não só transmitem informação como também moldam atitudes. Segundo o autor, crianças e adolescentes nos Estados Unidos são expostos a 3000 comerciais por dia. Eles se tornaram alvo de uma indústria de 250 bilhões de dólares anuais com 900 mil marcas para serem vendidas.

McNeal (1999 apud STORY; FRENCH, 2004) afirma que cerca de 1 bilhão de dólares são gastos anualmente nos Estados Unidos com propagandas de alimentos direcionados para crianças, a grande maioria vinculadas na televisão. Em soma com esse valor, cerca de 4,5 bilhões de dólares são gastos com promoções (como prêmios, amostras grátis e concursos) que visam atingir os jovens, e esta soma diz respeito somente a produtos que buscam divulgar alimentos.

Para Marcondes Filho (1988, p. 79), a publicidade atinge o seu ápice de possibilidades na televisão. O autor lembra que a maneira com que se faz publicidade é a mesma para se fazer televisão e que a publicidade "trabalha com modelos: modelos de beleza, de sensualidade, de elegância, de cor, de jeito de falar, de andar, de se alimentar, de namorar, enfim, modelos para todas as situações da vida." A publicidade busca impor valores muito mais do que só oferecê-los ao seu público. Além disso, ela é responsável por veicular valores. Com a finalidade de influenciar atitudes e comportamentos de forma a valorizar seus produtos e serviços, a publicidade constrói seu mundo de fantasia de forma a incentivar sua experimentação na realidade. Para Marcondes Filho (1988, p. 80) o produto é totalmente secundário, o que seduz seus usuários são as promessas embutidas naquele uso, naquela compra, aquilo que o produto representa, "o objeto simboliza para o consumidor uma síntese daquela vida. Adquirir uma roupa, um perfume, uma jóia, significa pertencer àqueles ambientes".

Rezende e Rezende (1993, p.7) dizem que "como mercadoria, a tevê vende todos os valores, de produtos de limpeza a idéias, sentimentos e atitudes." Para os 
autores, devido ao fato de a televisão transmitir mensagens de alto grau de verossimilhança torna-se difícil duvidar daquilo que é vinculado nela. A preocupação fundamental não é proibir a publicidade dirigida ao público infantil, mas regularizá-la de forma que os direitos das crianças sejam preservados e sua infância não seja comercializada. Para Ceccarelli (2000) o que chama atenção e constitui uma relação perigosa é o fato de que ao estabelecer uma relação com o telespectador, essa identificação seja capaz de criar referências ético-morais que não sejam adequadas e que sejam diferentes daquelas necessárias para que se construa uma estrutura social baseada em respeito e nos direitos do cidadão. Em lares em que as crianças assistem a diversos conteúdos sem o acompanhamento dos pais para que possam esclarecer ou orientar sobre possíveis mensagens apresentadas a preocupação é ainda maior, pois uma vez que o modelo familiar não está presente a criança pode tomar como exemplo aquilo que aprende através de outros canais ou modelos.

Kotler e Keller (2006b) lembram que

atualmente, as empresas estão mais propensas a usar a internet para
mostrar seus produtos às crianças e Ihes pedir informações de marketing.
Afinal, milhões de crianças e jovens com menos de 17 anos estão online.
Para se conectar a eles, as empresas oferecem brindes em troca de
informações pessoais (KOTLER; KELLER, 2006b, p. 179).

Para as crianças do novo milênio, a internet talvez seja a mais importante entre todas as mídias. Atualmente, computadores podem ser usados para enviar e-mails, para jogar vídeo-game, assistir filmes, ouvir música e acessar a internet. Além disso, por meio do computador, também já é possível assistir à programação televisiva de muitos canais de entretenimento. A internet também promove a publicidade. Muitos sites têm como alvo as crianças, e solicitam informações pessoais sem solicitar autorização dos responsáveis. Além disso, as empresas associam suas marcas à diversão e descontração, promovendo jogos, brincadeiras, papéis de parede para computador, desenhos e uma infinidade de atrações sempre com a mascote, o símbolo ou garoto propaganda da marca como personagem principal, onde as técnicas interativas de marketing promovem a marca em ambientes online cuidadosamente concebidos para as crianças.

As técnicas de marketing utilizadas para atrair a audiência e aumentar a venda de produtos são as mais diversificadas possíveis. Todas as práticas são desenvolvidas para acentuar os ambientes relacionados com a marca, promovendo uma futura 
lealdade do consumidor. Segundo Valkenburg (2000) algumas das práticas mais comuns são:

- $\quad$ repetição: envolve simplesmente repetir o mesmo comercial por várias vezes. A idéia da familiaridade com o produto aumenta a probabilidade da compra e uso do produto;

- chamar a atenção com características da produção da propaganda: essa prática é utilizada para atrair crianças interessadas no conteúdo dos comerciais. As características concentradas nos anúncios de televisão incluem muita ação e movimento, ritmo rápido, efeitos sonoros e música alta;

- personagens de desenho e brindes: diz respeito à utilização de personagens que são associados à empresa e, portanto promovem o nome da marca. As empresas usam os mesmos personagens em campanhas online e na televisão, além de utilizarem brindes, como pequenos brinquedos, em lanches de fast-food - comida rápida;

- uso de celebridades: O apoio de celebridades a determinadas marcas auxilia na venda de produtos. Crianças que gostam da celebridade que promove a marca provavelmente realizam ou solicitam a compra do produto;

- o posicionamento do produto: quando as marcas não são mais somente utilizadas pelos personagens, mas se tornam o próprio personagem, ou quando anunciantes promovem suas marcas em sites da internet utilizados pelas crianças;

- marketing viral: considerado o burburinho que se cria quando pessoas falam sobre determinados produtos umas para as outras, seja no mundo "real"pessoalmente, seja via internet. Fazem parte do marketing viral vídeos promocionais que aparentemente não possuem conteúdo relacionado com a marca, e-mails enviados por amigos com a promoção de produtos etc.

Assim, a multiplicidade de canais encontrados pela indústria para alcançar este público tem se tornado cada dia mais diversificado. São revistas voltadas ao público infantil, com diversas inserções publicitárias em suas páginas, anúncios em televisão, o apelo de personagens infantis em bebidas, comidas e anúncios de fastfood - comida-rápida. É preciso que o marketing dirigido ao público infantil seja 
pautado numa relação ética, com propósito de auxiliar no processo educativo destes indivíduos e que ao promover valores não realize distorções da realidade nem permita discriminações de qualquer tipo (LINN 2006).

Dada a importância de se entender as crianças enquanto consumidoras, a seguir será apresentado o conteúdo sobre este papel que elas exercem no mercado.

\subsubsection{Compradoras e influenciadoras das compras}

Em uma sociedade altamente capitalista, devido à alta competitividade do mercado, o marketing desenvolveu a tendência de segmentar nichos cada vez mais específicos em suas ações e o desenvolvimento da ciência auxilia na contribuição do aumento de estudos acerca de públicos antes não visados, como as crianças.

Shoham e Dalakas (2005) ao realizarem estudo em Israel para verificar a influência das crianças nas decisões de consumo da família, constataram que, independente da cultura, as crianças exercem alta influência nas compras, principalmente naquelas que consideram mais relevantes para si próprias. Os autores realizaram uma comparação de resultados de estudos realizados nos Estados Unidos com os resultados encontrados na pesquisa com crianças israelitas.

No Brasil, Silva, Avanzi e Silva (2007) verificaram que os pais consideram suas escolhas de roteiros turísticos levando direta ou indiretamente as opiniões dos filhos em conta, o que ressalta o poder de influência destas crianças na tomada de decisão familiar no país.

O estudo Kids Power - Poder das crianças (2007), realizado pelo Instituto de pesquisa TNS InterScience, mostrou que $71 \%$ das mães brasileiras com filhos entre 3 e 9 anos estão dispostas a comprar as marcas que as crianças pedem. Além disso, $52 \%$ destas crianças possuem um poder de compra direto, pois recebem dinheiro dos pais. Destes, $13 \%$ recebem dinheiro todos os dias, $29 \%$ recebem uma vez por semana, $8 \%$ recebem a cada 15 dias, $19 \%$ uma vez por mês e $32 \%$ não possuem uma freqüência pré-estipulada para o recebimento do dinheiro. A pesquisa demonstrou também que $59 \%$ das crianças gastam todo o dinheiro que recebem e 
apenas 39\% guardam a quantia recebida, o maior e o menor índice, respectivamente, entre os países pesquisados - Brasil, Argentina e México.

A pesquisa mostra, ainda, a reação das crianças quando as mães não compram aquilo que elas gostariam. Verificou-se que $57 \%$ são insistentes, deixam de pedir o produto por um tempo e voltam a pedir logo em seguida, 34\% são razoáveis, entendem e não pedem mais e $9 \%$ brigam, protestam, choram, gritam ou esperneiam quando não conseguem o que desejam.

McNeal (1998) lembra que produtos e serviços antes voltados para adultos hoje também estão disponíveis em versões para as crianças. Para ele, existem duas formas pelas quais as crianças influenciam as compras feitas pelos pais: de maneira direta e de maneira indireta. A influência direta é realizada através de pedidos, exigências e dicas. Já a influência indireta significa que os pais conhecem os produtos e marcas que seus filhos preferem e usam, sem que as crianças tenham que Ihes dizer. McNeal (2000 apud GROSSI; SANTOS, 2007) afirma que o público infantil representa três formas de mercado: um mercado primário, onde as crianças gastam seu dinheiro de acordo com seus desejos e necessidades; um mercado secundário, onde ocorre o gasto do dinheiro dos responsáveis em benefício da própria criança; e um mercado de futuro de todos os bens e serviços, onde a máxima de fidelizar hoje para garantir o consumidor de amanhã se faz verdadeira.

Silva, Avanzi e Silva (2007) observam que as crianças passam por três etapas em seu desenvolvimento: o universo das observações (0-2 anos); o universo das indagações (3-5 anos) e o universo racional (6-12 anos) e que já nas duas últimas etapas exercem influência direta nas compras realizadas pelos pais. $\mathrm{Na}$ primeira etapa, embora as crianças não realizem efetivamente a compra, elas são grandes influenciadoras, uma vez que os pais passam a comprar os produtos que com o tempo percebem serem os preferidos dos filhos. Essa constatação dos autores vai ao encontro da influência indireta relatada por McNeal (1998), e demonstra que mesmo nas situações em que não são os agentes finais das compras as crianças se posicionam de maneira importante para que a compra seja efetuada.

Nota-se que ao buscarem realizar seus desejos de consumo influenciando o comportamento de compra dos responsáveis, o público infantil já formalizou em seus pensamentos suas preferências por determinadas marcas e produtos em detrimento 
de outros e esse reconhecimento demonstra que a exposição das crianças ao marketing destes produtos resultou em uma identificação do público com o produto.

Strasburger (2004) afirma que crianças abaixo dos 12 anos de idade gastam por ano 25 bilhões de dólares e que juntamente com os adolescentes eles influenciam 200 bilhões de dólares anuais em compras feitas por seus pais.

Segundo Calvert (2008) estudiosos estimam que crianças dos 4 aos 14 anos de idade tenham influenciado mais de 500 bilhões de dólares anuais em compras para casa. Os publicitários já perceberam que influenciar os jovens é influenciar a decisão de compra de toda a família. Valkenburg (2000) concorda com estas afirmações e reforça que as crianças hoje não somente possuem grandes quantidades de dinheiro para gastar consigo mesmas, como influenciam tremendamente as compras dos responsáveis. Além de instruções sobre as compras da casa, orientando na compra de doces, cereais e lanches, à medida que crescem eles também influenciam diretamente a escolha dos pais por restaurantes, viagens e até carros novos.

Diversas autoras (GROSSI; SANTOS, 2007; LINN, 2006; SCHOR, 2004) fazem referências às inúmeras táticas promovidas pelas empresas para promoção de seus produtos. Linn (2006, p.58) lembra que o "fator amolação" foi objeto de estudo de diversas empresas, de forma a descobrir "quais tipos de pais estão mais propensos a ceder às amolações", sendo os pais divorciados e aqueles com crianças pequenas e adolescentes os que aparecem no topo da lista . O intuito da pesquisa realizada pelas empresas privadas foi encontrar meios para aumentar suas vendas a partir do fator amolação, verificando, segundo Linn (2006, p.58), "algumas coisas pelas quais as crianças normalmente amolam os pais, estimando a freqüência de sucesso para cada tipo de pedido".

As crianças exercem sim influência no processo de decisão de compras de seus pais e essa influência existe da necessidade que sentem de possuir determinados bens e produtos. Verifica-se, portanto, que a publicidade influencia e molda os gostos e desejos das crianças.

Para que se entenda a respeito da imersão das crianças na cultura do consumo, é preciso saber mais sobre o envolvimento do consumidor infantil, tema da próxima seção. 


\subsection{O envolvimento do consumidor}

Neste trabalho, o envolvimento do consumidor será caracterizado pela definição utilizada por Schor (2004), onde o envolvimento do consumidor é entendido como a imersão da criança na cultura do consumo, como consumismo.

É fundamental o estudo a respeito do impacto do novo ambiente de consumo, como um todo, na vida das crianças. No entanto, a cultura do consumo é uma realidade abrangente difícil de se definir e de se mensurar. O estudo de Schor (2004) procura quantificar o que ela denomina de "envolvimento do consumidor". Portanto, para Schor (2004), o fato de ser impossível encontrar um, ou até dois, indicadores que de forma precisa e resumida expressem o que seria este envolvimento do consumidor, torna necessária a realização de uma caracterização ampla de atitudes de consumidores, valores esposados e atividades realizadas por eles. Então, a escala desenvolvida pela autora trabalha o envolvimento do consumidor como um construto multi-dimensional composto por três fatores de primeira ordem, sendo eles: insatisfação, orientação do consumidor e reconhecimento da marca. O envolvimento do consumidor é considerado, então, como o envolvimento e a imersão das crianças na cultura do consumo.

Schor (2004) afirma que a relação das crianças enquanto consumidoras data de muitos anos e lembra que alguns produtos infantis, como a literatura e o vestuário, estão disponíveis para este público há séculos.

Para Schor (2004, p. 9), a mudança ocorrida no rumo da imersão das crianças na cultura do consumo é um fato sem precedentes. Para ela, antigamente o consumo era moderado em comparação com outras atividades como brincadeiras, lazer e a escola. Hoje, as horas vagas são preenchidas pelo marketing que "substitui as sociabilidades não estruturadas". No mais, segundo Schor (2004),

os jovens são o repositório da informação de consumo e da identificação das marcas. São os primeiros utilizadores das novas tecnologias e os mais atentos aos produtos, marcas e últimos lançamentos. O mundo infantil é cada vez mais construído em torno do consumo, quando as marcas e os produtos determinam quem está "por dentro" e que está "por fora", quem é "quente" e quem não é, quem terá amigos e quem não os terá, quem alcançará posições sociais de destaque e quem não será bem-sucedido nisso. (SCHOR, 2004, p. 4) 
Bottomley et al. (2007) afirmam que os pesquisadores têm se interessado no materialismo e na cultura do consumo há mais de 30 anos, embora a maioria dos trabalhos tenha seu foco nos adultos em vez das crianças. Muitas escalas para medir o materialismo entre adultos foram desenvolvidas ao longo dos anos, como a de Belks (1985 apud BOTTOMLEY et al., 2007), baseada em traços de personalidade e a de Richins e Dawson (1992 apud BOTTOMLEY et al., 2007), que consideram o materialismo como um sistema de valores pessoais, crenças solidificadas que definiriam o que é importante para o indivíduo.

Para Bottomley et al. (2007), é fundamental que sejam utilizadas escalas adequadas para o público infantil na medição do materialismo, pois é evidente a necessidade de métodos próprios para este público alvo, com características únicas e tão diferentes dos adultos.

As escalas desenvolvidas com foco no público infantil são consideradas por Bottomley et al. (2007) como confiáveis, com critérios abrangentes de validade, mas que ainda deixam a desejar sobre a dimensão do construto analisado, no caso o materialismo infantil.

Neste trabalho será utilizada a escala de envolvimento do consumidor desenvolvida por Schor (2004) que tem como objetivo focar menos os traços de personalidade e os valores pessoais que as crianças podem usar para interpretar o mundo que as cerca - visto os motivos já citados sobre a utilização destas características - e focar no comportamento do consumidor infantil.

A seguir, serão sintetizados os subfatores da escala a ser utilizada no trabalho.

\subsubsection{Insatisfação}

Anúncios publicitários acentuam o consumismo em crianças porque são desenvolvidos para despertar desejos que de outra forma não seriam salientados. Para Wulfmeyer e Mueller (1992 apud BUIJZEN; VALKENBURG, 2003), as propagandas divulgam a ideologia de que posses e bens são importantes e que qualidades como beleza, sucesso e felicidade podem ser obtidas somente por bens materiais. Assim, as crianças compreendem em suas mentes que é fundamental a 
posse de bens que possam proporcionar tudo aquilo que elas desejam em termos de satisfação pessoal.

Para Buijzen e Valkenburg (2003), as crianças mais novas (menores de 8 anos) tendem a entrar mais facilmente em conflito com os pais do que as crianças mais velhas. Isto pode ser explicado devido ao fato destas crianças realizarem a maior parte de suas compras através de solicitações aos pais. Além disso, quando consideram um item extremamente atrativo, crianças mais novas tendem a focar toda sua atenção nos aspectos sedutores do que as estimula e acham muito difícil resistir ao foco de sua adoração, podendo causar conflitos quando os responsáveis não estão dispostos a satisfazer seus desejos. No mais, quando suas expectativas não são correspondidas as crianças menores normalmente choram, pedem e reclamam, demonstrando raiva e frustração para tentar convencer seus pais. À medida que crescem, as crianças desenvolvem uma maior sofisticação de técnicas de persuasão dos pais, como negociação e charme.

Para Strasburger (2001), crianças com idade entre os 8 e 10 anos têm habilidade cognitiva para processar propagandas mas não necessariamente o fazem. Já crianças de 11 e 12 anos possuem o pensamento mais diversificado, com pensamentos concretos. Ainda assim eles podem ser persuadidos pelas mensagens emotivas do marketing, que joga com suas preocupações sobre aparência, autoestima e sexualidade.

De acordo com Calvert (2008), a exposição das crianças ao marketing pode ocasionar resultados negativos, incluindo conflitos entre pais e filhos, cinismo, obesidade, e atitudes consumistas. A autora lembra que os pais são os responsáveis por prover os recursos financeiros que permitem que as crianças façam compras. O modo como os responsáveis se relacionam com o dinheiro e como ensinam essas crianças a utilizá-lo pode influenciar a maneira como as crianças respondem ao marketing de produtos direcionados a eles, e como este marketing irá afetar o resultado do desenvolvimento das crianças.

Para Schor (2004, p. 204), o consumo é uma atividade intrinsecamente social, e aquilo que uma pessoa compra, veste ou come afeta o desejo e o comportamento dos que estão à sua volta. As crianças principalmente, "se preocupam, às vezes desesperadamente, com o modo como suas escolhas serão recebidas pelos colegas". 
Para Atkin (1980 apud BUIJZEN; VALKENBURG, 2003), as propagandas representam um mundo de pessoas bonitas e produtos desejáveis. Quando uma criança assiste a comerciais de televisão e compara a sua situação com a situação idealizada no comercial, a discrepância entre os dois mundos pode causar tristeza.

O público infantil encontra-se tão imerso na cultura do consumo que o fato de um colega possuir determinado bem material pode ser motivo de frustração quando a outra criança também não o possui. Não ter os bens a que aspiram, perceber que as outras crianças possuem mais coisas, não ter dinheiro para realizar as compras tão desejadas, são vistos como motivos de insatisfação para o público infantil. A insatisfação é gerada justamente quando a criança é exposta a padrões diferentes dos seus, quando ela exerce a comparação com outras crianças e senti-se inferiorizada por não ser igual àquele padrão estipulado (SCHOR, 2004).

A seguir, será apresentado o fator Orientação do consumidor.

\subsubsection{Orientação do consumidor}

Segundo Roberts e Manolis (2000), para os pesquisadores e para os agentes de marketing, nenhuma característica demográfica é mais importante do que a idade. Mitchell (1995 apud ROBERTS; MANOLIS, 2000) afirma que a idade possui um papel integral para determinar o comportamento do consumidor.

Para McNeal (1979), as crianças de aproximadamente 4 anos podem ser consideradas consumidoras por meio de alguns pontos de vista. De um ponto de vista econômico elas possuem desejos e habilidades para comprar. Pelo lado psicológico, elas possuem necessidades e habilidades cognitivas para expressar essas vontades para o mercado. Pelo lado dos negócios, as crianças são consumidoras na medida em que planejam suas compras, procuram informações sobre os produtos, realizam verdadeiramente o ato de comprar, agem normalmente com o seu próprio dinheiro e avaliam as compras realizadas. Para o autor, independente das características individuais de cada família, os pais entendem que se tornar consumidor faz parte do processo natural de crescimento. Crianças de quatro anos (ou menores) são levadas para passeios nos shoppings e são 
introduzidas pelos pais aos componentes principais do mercado - dinheiro, produtos e lojas. Para McNeal (1979), os pais não parecem se esforçar para esconder o mercado de consumo dos menores ou para protegê-los dos efeitos deste mercado.

Valkenburg e Cantor (2001) afirmam que o comportamento do consumidor possui quatro características: sentir desejos e preferências, procurar meios de satisfazer esses desejos, fazer uma escolha e uma compra e avaliar os produtos e suas alternativas. As autoras afirmam que $40 \%$ dos pais de crianças de 2 anos dizem que seus filhos reconhecem nas lojas produtos promovidos por propagandas. Com 0 aumento da idade essa percentagem aumenta: $60 \%$ dos pais de crianças de 3 anos, $84 \%$ dos pais de crianças de 4 anos e $88 \%$ dos pais de crianças de 5 anos afirmam que os filhos reconhecem os produtos que viram em propagandas.

Valkenburg e Cantor (2001) lembram que as crianças em idade pré-escolar acreditam que as informações vinculadas nos comerciais sejam verdadeiras, e que eles têm dificuldade em distinguir fantasia e realidade. As autoras reforçam que as crianças pequenas, de 3 e 4 anos, têm dificuldade de retirar sua atenção dos produtos que consideram mais atrativos, pois para eles brinquedos e doces são praticamente irresistíveis, e justamente por isso muitas vezes tendem a entrar em conflito com os responsáveis quando as compras são negadas. McNeal (1979) reforça que enquanto consumidoras as crianças de cinco anos também compram itens de imediata gratificação própria: doces, bebidas, sorvetes, chicletes etc. Ocasionalmente comprarão um brinquedo ou presente para si mesmos.

Calvert (2008) acredita que as crianças dos 2 aos 7 anos de idade são especialmente ligadas a características como a apresentação do produto além de acreditarem que eventos imaginários e personagens fictícios podem ser reais. Por volta dos 7 aos 11 anos as crianças passam então a entender o mundo de uma maneira mais realista, e começam a pesquisar informações sobre os produtos na internet e outros lugares, não ficando restritos àquilo que é veiculado nos comerciais.

Para Schor (2004), as crianças estão se tornando consumidoras cada vez mais cedo. Segundo a autora estima-se que as crianças entre os 6 e 12 anos visitem lojas duas a três vezes por semana e coloquem no carrinho de compras seis itens em cada visita. 
Para McNeal (1979), dos 7 aos 12 anos de idade, o papel enquanto consumidor será rotineiro para as crianças, elas freqüentemente comprarão coisas. Nesta idade, elas não irão considerar o consumo como um dever ou privilégio, mas como um comportamento normal de pessoas da sua idade ou mais velhos. A esta altura, elas já estarão comprando em diversas lojas, já irão devolver e detectar produtos com defeitos, irão reclamar de produtos que não correspondam à promessa vinculada em sua propaganda, serão críticas quanto ao que assistem, comprarão não só para si próprias mas para os outros e já terão suas preferências por determinadas marcas que mudarão com o tempo ou com a influência dos colegas. Neste momento, o autor afirma que a criança pode não estar pagando as contas da casa e pode não prever os gastos mensais da casa com supermercado, mas de qualquer ponto de vista, incluindo o ponto de vista de um adulto, ela já será uma consumidora.

McNeal (1979) lembra, ainda, que para as crianças, a fonte mais confiável de informações para compras são os pais, que confirmam as informações que as crianças recebem de outras fontes. As propagandas e os amigos são a segunda fonte mais importante, onde existem dois fluxos de informações: um da televisão para as crianças, que é confirmado pelos amigos e pais; e o outro originado dos amigos que é confirmado pela televisão. Outra importante fonte de informação são as lojas, ou não exatamente as lojas, mas seus produtos, embalagens e marcas.

Os diversos componentes que fazem parte do mercado de consumo são entendidos pelas crianças de diferentes formas de acordo com a idade que possuem. As crianças aos 4 anos de idade já têm a noção de que o dinheiro serve para comprar coisas e por volta dos 9 anos eles já entendem as razões para se guardar dinheiro. McNeal (1979, p. 354) afirma que "independente da idade, há uma pequena questão sobre o significado do dinheiro para as crianças. É o requisito básico para se obter coisas boas na vida".

As lojas para o público infantil simbolizam exatamente o lugar onde estão as coisas que o dinheiro pode comprar. A partir dos 9 anos eles entendem que seus gastos contribuem para o lucro da loja, ainda assim eles não fazem idéia do tamanho do lucro que isso simboliza e nem têm interesse em saber mais a respeito.

Segundo Valkenburg e Cantor (2001), a faixa etária que compreende as crianças dos 8 aos 12 anos credita um papel muito importante à opinião dos amigos. Este é também um período onde o olhar das crianças para detalhes e qualidade dos 
produtos se desenvolve, além também do desenvolvimento de suas habilidades de avaliar criticamente e comparar produtos e informações. Por desenvolverem um forte comprometimento e lealdade às normas dos grupos que freqüentam, estas crianças são incrivelmente sensíveis aos pensamentos, opiniões, julgamentos e avaliações das outras crianças, e tornam-se muito perceptivas ao que é legal, descolado e ao que é moderno. No mais, elas prestam muita atenção no modo como se comportam em público e nas maneiras que podem encontrar para evitar serem ridicularizadas no que diz respeito às roupas que usam $e$, inclusive, no que diz respeito às suas preferências televisivas. É também nessa idade que elas aumentam sua lealdade às marcas.

Para as autoras, por volta dos 9 - 10 anos de idade, as crianças começam a perder o interesse em brinquedos e desenvolvem uma preferência por produtos com uma função social, como música, equipamentos eletrônicos e equipamentos para esporte.

Para Jovchelovitch (2005 apud GROSSI; SANTOS, 2007, p.448), os brinquedos são formas de apego da criança embora a sociedade de consumo esteja modificando esta função. Para a autora, "o excesso de ofertas vem agravando a característica da descartabilidade dos produtos logo após serem adquiridos, pois já está em voga o desejo por outra aquisição".

Linn (2006) critica o fato de pais, empresas e a sociedade encorajarem valores materialistas nas crianças cada vez mais cedo, o que resultará em adultos mais consumistas e orientados a propagar essa característica a novas gerações.

Furnham (2001 apud LAURINDO; LEAL, 2008) acredita que apesar dos gostos parecidos numa mesma faixa etária, o fator social pode afetar os hábitos de consumo. $O$ autor salienta que a aprendizagem de consumo será diferente para as crianças pobres, tendo em vista que na maioria das vezes elas não podem consumir da mesma forma que a criança de classe elevada. Gunter e Furnham (1998 apud VALKENBURG, 2000) reiteram que além do nível socioeconômico das crianças, a freqüência e o tipo de envolvimento entre pais e filhos e o envolvimento das crianças com seus colegas também são considerados fatores importantes na construção do comportamento orientado ou não ao consumo. 


\subsubsection{Reconhecimento da marca}

Ross e Harradiner (2004), em estudo realizado com crianças de 5 a 6 anos e seus pais, constataram que os responsáveis acreditam que as crianças não têm grande conhecimento sobre marcas e, no entanto, acreditam que a constante exposição dos filhos às marcas resultará em alguma influência. Diferente do que pensam os pais, o estudo comprovou que desde pequenas (5-6 anos) as crianças já têm noção sobre as marcas e que, à medida que crescem, essa noção torna-se mais sofisticada. A necessidade de ter um produto de marca reconhecida é expressa pelas crianças entre 9 e 11 anos que afirmam que prefeririam ter produtos que fossem falsos mas parecessem originais do que ter um produto de marca desconhecida, o que coincidiu com a opinião dos responsáveis que afirmaram que seus filhos eram preocupados em ter produtos de etiquetas certas, conhecidas.

Para McNeal (1999 apud STORY; FRENCH, 2004) o marketing pesado direcionado para os jovens, especialmente as crianças mais novas, parece estar sendo dirigido pelo desejo de desenvolver e construir o reconhecimento da marca, sua preferência e lealdade. Os analistas de marketing acreditam que a preferência por marcas começa antes do comportamento de compra ser iniciado. Para o autor, a preferência das crianças por determinada marca está relacionada a dois fatores: experiências positivas vivenciadas pelas crianças com a marca e o fato de os pais gostarem da marca. Ele lembra que os esforços de marketing para criar o reconhecimento da marca têm como alvo crianças cada vez mais novas, uma vez que sabem que elas são influenciadoras de compras e tem grande habilidade em "amolar" os pais com pedidos constantes por produtos específicos. A primeira solicitação de uma criança por um produto ocorre por volta dos dois anos de idade e $75 \%$ das vezes esse pedido ocorre em um supermercado. Os primeiros pedidos são em $47 \%$ das vezes por cereais matinais, $30 \%$ para lanches e bebidas e $21 \%$ para brinquedos. Além disso, os pedidos são feitos na maioria das vezes através do nome da marca específica que desejam.

Para McNeal (1979), as marcas de muitos produtos que as crianças compram são importantes para elas. O reconhecimento da marca é alto. Crianças que ainda não sabem ler conseguem reconhecer e pronunciar o nome de uma marca quando ela 
Ihes é apresentada na forma de seu símbolo, como em uma embalagem. A preferência por determinadas marcas existe em todas as idades, mas parece ser maior entre os mais novos, mas isso acontece porque aparentemente os mais velhos já elegeram marcas substitutas. Além do mais, as marcas possuem atributos, elas podem ser caras ou baratas, de alta ou baixa qualidade e orientadas para adultos ou crianças.

Montigneaux (2003 apud LAURINDO; LEAL, 2008) explica que crianças de 5 a 6 anos estão numa fase em que começam a comparar produtos utilizando como base atributos abstratos ou funcionais, o uso, o logotipo e elementos figurados. Aos seis anos estas crianças conseguem citar ao menos um nome de marca por categoria de produto, mas lembra que para estas crianças a marca serve somente para literalmente nomear o produto. Para o autor, é a partir dos 7 a 8 anos de idade que o conceito de marca nasce.

Já Baader (2002 apud LAURINDO; LEAL, 2008) afirma que desde cedo, até mesmo antes da alfabetização as crianças já conhecem personagens, marcas, produtos e já utilizam critérios próprios para avaliá-los e conceituá-los.

Para McNeal (1999 apud CONNOR, 2008) os analistas de marketing estão ávidos para atingir as crianças pequenas, não necessariamente para promover determinados produtos, mas com o objetivo de construir lealdade à marca, com base na teoria de que quanto mais cedo o reconhecimento com a marca é estabelecido, mais forte será a lealdade à marca quando a criança crescer.

Para Achenreiner e John (2003), a atual geração de jovens consumidores têm se destacado como a que possui maior consciência de marcas, em virtude da profundidade e tamanho de conhecimento e preferências por marcas específicas. As autoras lembram que as crianças reconhecem nomes de marcas cada vez mais cedo, por volta dos 3 - 4 anos de idade e que este reconhecimento e solicitação por marcas aumenta na medida em que as crianças crescem. Na idade entre $7-8$ anos de idade, o público infantil é capaz de nomear inúmeras marcas por categorias de produtos, mencionar marcas como um tipo de informação importante sobre um produto, além de solicitar produtos pelo nome de suas marcas. Para as autoras, isso fornece suporte para se afirmar que as marcas são importantes para as crianças, além de sugerir que esta importância cresce ao passo em que crescem também os consumidores. 
Entender o significado que está atrelado a possuir certos produtos ou marcas é conhecido como simbolismo do consumo, e este simbolismo é um importante aspecto da socialização das crianças no mundo do consumo. Achenreiner e John (2003) constataram que o desenvolvimento das habilidades das crianças em reconhecer símbolos de consumo começa por volta dos 7 - 8 anos de idade. Neste ponto, contudo, eles estão mais ligados a características perceptuais do ambiente que os rodeia e estão mais propensos a usar esses tipos de características para compreender o simbolismo por trás de determinados produtos. As percepções se tornam mais refinadas enquanto as crianças crescem. Por volta dos 11 - 12 anos de idade, os indivíduos já são capazes de decodificar símbolos de consumo baseados no nome das marcas, formando impressões sobre os donos dos produtos baseados na imagem e nos significados das marcas identificadas nos usuários.

Assim, segundo Achenreiner e John (2003), a consciência das crianças sobre as marcas pode ser considerada um fenômeno diferente se levada em consideração a idade da criança. A noção da marca em crianças mais novas tende a ser relacionada pela familiaridade e visibilidade do nome da marca em comerciais, lojas e entre os amigos. Eles podem solicitar um determinado tênis somente porque viram outra criança usando e o acharam legal. Já crianças mais velhas relacionam as marcas de um modo mais profundo, buscando entender o que a marca expressa e o que diz sobre eles. Sendo assim, eles podem pedir por um determinado tênis porque aquela marca é para grandes corredores, assim os distinguindo pelo uso do atributo ligado à marca. 


\section{MÉTODOS E TÉCNICAS DE PESQUISA}

Neste capítulo serão apresentadas informações sobre o tipo de pesquisa que foi realizada, as organizações que participaram da pesquisa, bem como a descrição dos procedimentos de coleta e análise de dados. Além disso, serão caracterizados o instrumento de pesquisa e a população e amostra.

\subsection{Tipo e descrição geral da pesquisa}

Para Vergara (2000), a pesquisa pode ser classificada quanto aos fins e quanto aos meios. Quanto aos fins, esta foi uma pesquisa descritiva, pois expôs características de um determinado fenômeno, e quanto aos meios, foi uma pesquisa de campo e bibliográfica.

A pesquisa de campo, segundo Vergara (2000), é uma investigação empírica que se dá no local onde ocorre o fenômeno e a pesquisa bibliográfica é o estudo realizado com o que foi publicado sobre o assunto em livros, artigos científicos e rede eletrônica para a realização da fundamentação teórica e metodológica do estudo.

A pesquisa realizada possuiu natureza quantitativa, pois comparou dados numéricos sobre o envolvimento do consumidor infantil entre crianças de escolas públicas e privadas de Brasília, demonstrando a importância da existência de um maior número de estudos que busquem conscientizar pais e responsáveis sobre a necessidade do cuidado e atenção que devem ser tomados com o espaço do consumo existente na vida das crianças.

Além disso, a pesquisa fez uso de um instrumento predefinido, neste caso, o questionário. 


\subsection{Caracterização do setor}

Segundo dados do Censo da Educação Básica de 2009 realizado pelo Instituto Nacional de Estudos e Pesquisas (INEP), o Brasil possui 152.251 mil escolas de ensino fundamental, sendo 833 no Distrito Federal.

O ensino fundamental promove a formação de crianças com idade média entre os 6 e 14 anos, divididas em 9 anos - antigamente denominados séries. Ele constitui dois ciclos, os primeiros 5 anos correspondem aos anos iniciais, onde normalmente o trabalho é desenvolvido por um único professor, e os últimos 4 anos, que correspondem aos anos finais, onde uma equipe de professores de diferentes disciplinas realiza o trabalho educacional.

A matrícula das crianças compreendidas nesta faixa etária é obrigatória, segundo o inciso I do artigo $4^{\circ}$ da Lei 9.394/96, que estabelece as diretrizes e bases da educação nacional. Além disso, de acordo com o artigo $6^{\circ}$ da Lei 9.394/96 é responsabilidade dos pais efetuar a matrícula, e segundo o artigo $4^{\circ}$ da mesma Lei, o governo deve garantir vagas para todas as crianças.

No ano de 2009, o Distrito Federal possuía 418.913 mil alunos matriculados no Ensino Fundamental.

\subsection{População e amostra}

Várias instituições de ensino foram contatadas para a realização da pesquisa e àquelas que autorizaram o trabalho foram então visitadas. Assim, 6 instituições de Ensino Fundamental públicas e 2 instituições de Ensino Fundamental privadas participaram da realização deste trabalho. As instituições de ensino visitadas para a realização da pesquisa contam com 1.335 alunos matriculados no sexto ano, sendo 745 matriculados em escolas públicas e 590 matriculados em escolas privadas. Para a realização do survey foi realizada uma pesquisa censitária com os alunos matriculados no $6^{\circ}$ ano (antiga $5^{\mathrm{a}}$ série) de cada uma das escolas. 


\subsection{Instrumento de pesquisa}

Bottomley et al. (2007) levantaram os problemas encontrados na utilização de escalas criadas para adultos serem utilizadas para medir o materialismo entre as crianças. Belks (1985 apud BOTTOMLEY ET AL., 2007) realizou seu trabalho com base na personalidade, mas para Bottomley et al. (2007, p. 4), é difícil chegar a um consenso sobre em que idade a personalidade de uma criança está suficientemente formada para que possa ser medida. Os autores acrescentam, também, que as crianças podem entender o mundo de uma forma diferente dos adultos, e assim "a noção de sucesso pode ser vivenciada de maneira diversa por crianças em um parquinho e por adultos no ambiente de trabalho" e, portanto, a escala desenvolvida por Richins e Dawson (1992 apud BOTTOMLEY ET AL. 2007), que leva em consideração valores pessoais de cada indivíduo para realizar a medição do materialismo, apresentaria problemas para ser utilizada com crianças. No mais, para os autores, questões com afirmações negativas podem ser de difícil compreensão para crianças, o que poderia resultar em dificuldade para responder às perguntas ou em respostas inacuradas, uma vez que estes itens demandam maiores habilidades cognitivas dos indivíduos. Sendo assim, é fundamental a utilização de uma escala desenvolvida especialmente para as crianças, que leve em consideração todas as peculiaridades referentes a este público.

O instrumento de pesquisa utilizado no trabalho foi o questionário desenvolvido por Schor (2004) e validado por Bottomley et al. (2007), apresentado no Anexo A. Ele contém 16 questões fechadas que medem o envolvimento do consumidor infantil, considerando o envolvimento do consumidor como um construto multidimensional que compreende outros três fatores de primeira ordem, sendo eles: insatisfação (itens 1, 3, 6, 8, 12 e 13), orientação do consumidor (itens 7, 9, 10, 11 e 15) e reconhecimento da marca (itens $2,4,5,14$ e 16). Além destas questões fechadas, o questionário é composto por dez questões sobre dados demográficos, que foram adaptadas, sobre os seguintes assuntos: idade, etnia, sexo, escolaridade e estado civil dos pais. A pesquisa realizada por Schor (2004, p.157) não pergunta sobre a situação financeira das famílias, pois segundo a autora "as crianças não costumam saber o valor da renda e outros dados econômicos". Por conta desta dificuldade, Schor (2004) utilizou a educação dos pais para inferir a classe socioeconômica da 
criança, uma prática usual em pesquisas, segundo a autora. Portanto, neste trabalho a inferência da classe socioeconômica das crianças será feita da mesma maneira. O questionário original foi formulado na língua inglesa e para a utilização neste estudo foi traduzido para o português pela pesquisadora.

Para Sampaio (2000) a faixa etária dos 8 aos 12 anos para a criança

é uma fase em que ela está interessada no porquê das coisas e faz
experiências para testar suas hipóteses. A criança amplia, nessa fase, o seu
horizonte de interesses, antes focalizado no âmbito da família, e desloca
sua atenção para a descoberta do mundo que se constitui para ela num
grande mistério e onde ela pretende vivenciar inúmeras aventuras
(SAMPAIO, 2000, p. 183).

Esta faixa etária é caracterizada por Vygotski (1996 apud FACCI, 2004) como a idade escolar e, para Davidov (1988 apud FACCI, 2004) é durante a fase de desenvolvimento escolar (8 aos 12 anos) que surgem a consciência e o pensamento teórico e desenvolvem-se, entre outras funções, as capacidades de reflexão, análise e planificação mental.

De maneira a facilitar o processo de aplicação dos questionários, o survey foi realizado com as crianças do $6^{\circ}$ ano do ensino fundamental, que estão incluídas na faixa etária dos 8 aos 12 anos.

\subsection{Procedimentos de coleta e de análise de dados}

A realização do estudo ocorreu com a prévia autorização das instituições de ensino, e, no caso das escolas públicas, contou também com a autorização da Diretoria Regional de Ensino do Plano Piloto/Cruzeiro. Os horários para aplicação dos questionários foram definidos de acordo com a conveniência das instituições. A pesquisa foi feita nos dias 21 e 24 de junho nas escolas privadas e no período de 28 de junho a 6 de julho nas escolas públicas.

Foi explicada às crianças a importância da participação de cada uma para a realização da pesquisa, ressaltando-se a confidencialidade das informações obtidas, a omissão de nomes e o comprometimento em compartilhar os resultados com os interessados. 
Responderam ao questionário todos os alunos que estavam presentes nas escolas no dia da aplicação. A limpeza dos dados foi realizada por meio da verificação de casos omissos (missing cases) e de casos extremos (outliers). Não foram entregues questionários com dados omissos em nenhuma das escolas, mas foram identificados 6 outliers univariados nas escolas públicas. Foram obtidos 568 questionários válidos nas escolas privadas. Nas escolas públicas foram obtidos 661 questionários, dos quais 74 foram descartados, pois não se enquadravam na faixa etária pesquisada (além dos 6 outliers excluídos), totalizando assim 581 questionários válidos. Portanto, foram aplicados um total de 1.229 questionários, sendo 1.149 o número total de questionários válidos.

Os questionários foram entregues pela pesquisadora em sala de aula para cada um dos alunos presentes. Foi feita a leitura do mesmo e os alunos foram orientados a levantarem a mão caso alguma dúvida surgisse. As crianças levaram, em média, 10 minutos para responder a todas as perguntas, e a grande maioria das dúvidas existentes surgiram nas questões 3,4 e 5 da parte I do questionário (apêndice $A$ ), pois as crianças não entendiam a nomenclatura utilizada para os níveis de ensino, era preciso que fosse explicado o que cada nível de ensino (fundamental, médio e superior) significava, além de apresentarem dificuldades na definição da raça a qual pertenciam.

A análise dos dados foi realizada baseada nas respostas obtidas nos questionários, com utilização do software Statistical Package for the Social Sciences (SPSS) versão 17.0. A medida descritiva utilizada para análise dos dados foi a média, além das freqüências de resposta. Também foi realizada uma análise inferencial por meio da Análise de Variância (ANOVA). De acordo com Stevenson (1997), a Análise de Variância é um teste de hipóteses de médias de duas ou mais amostras, e é um procedimento útil para avaliar se as médias das amostras são estatisticamente significantes. Assim, as hipóteses testadas foram:

$\mathrm{H}_{0}$ : $\mathrm{O}$ envolvimento do consumidor infantil é o mesmo para crianças de escolas públicas e privadas.

$\mathrm{H}_{1}$ : O envolvimento do consumidor infantil é maior para crianças de escolas públicas. Supondo-se inicialmente $\mathrm{H}_{0}$ como a hipótese verdadeira, a probabilidade de significância, ou valor p, é definida por Barbetta (2005, p. 200) como "a probabilidade 
de a estatística do teste acusar um resultado tanto ou mais distante do esperado". O nível de significância adotado na pesquisa foi de $5 \%$, sendo designado pela letra grega a. Desta forma:

$$
\begin{aligned}
& p>\alpha-\text { Aceita } H_{0} \text {, rejeita } H_{1} \\
& p \leq \alpha-\text { Rejeita } H_{0} \text {, aceita } H_{1}
\end{aligned}
$$




\section{RESULTADOS E DISCUSSÃO}

Durante a realização do trabalho, buscou-se demonstrar que existem diferenças no envolvimento do consumidor infantil entre crianças de escolas públicas e privadas. Para Schor (2004) a escolaridade dos pais pode ser utilizada para inferir a classe socioeconômica das crianças, e assume-se que as crianças de escolas públicas possuem um menor nível de renda, pertencendo, portanto, às classes menos favorecidas. Nesta pesquisa, verificou-se que $86,8 \%$ das mães e $88,4 \%$ dos pais de crianças de escolas privadas possuem o Ensino Superior completo enquanto apenas $14,3 \%$ das mães e $13,8 \%$ dos pais de crianças de escolas públicas possuem esta escolaridade, conforme pode ser observado nas tabelas 1 e 2 .

Tabela 1 - Escolaridade dos pais

\begin{tabular}{lll} 
& \multicolumn{3}{c}{ Tabela 1 - Escolaridade dos pais } \\
\hline & ESCOLAS PRIVADAS & ESCOLAS PÚBLICAS \\
\hline Ens. Fund. Incompleto & $0,4 \%$ & $22,4 \%$ \\
Ens. Fund. Completo & $0,9 \%$ & $9,8 \%$ \\
Ens. Med. Incompleto & $1,9 \%$ & $16 \%$ \\
Ens. Med. Completo & $4,9 \%$ & $28,2 \%$ \\
Ens. Sup. Incompleto & $3,5 \%$ & $9,8 \%$ \\
Ens. Sup. Completo & $88,4 \%$ & $13,8 \%$ \\
\hline
\end{tabular}

Tabela 2 - Escolaridade das mães

\begin{tabular}{lll}
\hline & ESCOLAS PRIVADAS & ESCOLAS PÚBLICAS \\
\hline Ens. Fund. Incompleto & $0,7 \%$ & $20 \%$ \\
Ens. Fund. Completo & $1,2 \%$ & $8,6 \%$ \\
Ens. Med. Incompleto & $1,1 \%$ & $18,8 \%$ \\
Ens. Med. Completo & $5,3 \%$ & $29,8 \%$ \\
Ens. Sup. Incompleto & $4,9 \%$ & $8,6 \%$ \\
Ens. Sup. Completo & $86,8 \%$ & $14,3 \%$ \\
\hline
\end{tabular}

A amostra da pesquisa possuiu um número similar de meninos e meninas, em sua maioria de 11 anos (tabelas 3 e 4).

\begin{tabular}{lll}
\multicolumn{2}{c}{ Tabela 3 - Sexo } \\
\hline & ESCOLAS & ESCOLAS \\
& PRIVADAS & PÚBLICAS \\
\hline Menino & $48,2 \%$ & $50,6 \%$ \\
Menina & $51,8 \%$ & $49,4 \%$ \\
\hline
\end{tabular}




\begin{tabular}{lll}
\multicolumn{2}{c}{ Tabela 4 - Idade } \\
\hline & ESCOLAS & ESCOLAS \\
& PRIVADAS & PÚBLICAS \\
\hline 9 anos & $0 \%$ & $0,2 \%$ \\
10 anos & $12,1 \%$ & $11 \%$ \\
11 anos & $84 \%$ & $62,8 \%$ \\
12 anos & $3,9 \%$ & $26 \%$ \\
\hline \multicolumn{3}{c}{ Tabela 5 - Raça / etnia } \\
\hline \multicolumn{3}{c}{ ESCOLAS } \\
\hline Branco & PRIVLAS & PÚBLICAS \\
Negro & $78,7 \%$ & $44,4 \%$ \\
Asiático & $6,2 \%$ & $32,4 \%$ \\
Índio & $2,5 \%$ & $2,1 \%$ \\
Outros & $3,5 \%$ & $7,6 \%$ \\
\hline
\end{tabular}

A caracterização do ambiente familiar feita pelos alunos das escolas privadas demonstra que $72,4 \%$ dos pais são casados ao passo que $18,8 \%$ são divorciados (as freqüências deste item podem ser observadas no gráfico 1), além disso, é possível verificar que a enorme maioria, $97,7 \%$, mora com a mãe enquanto $79 \%$ mora com os pais. Esse resultado pode ser atribuído ao fato de que muitas das crianças que afirmaram serem filhas de pais divorciados disseram morar com os dois, uma vez que passam uma semana com o pai e a outra semana com a mãe. Integrado a isso, há o fato das crianças que possuem pais casados morarem com ambos.

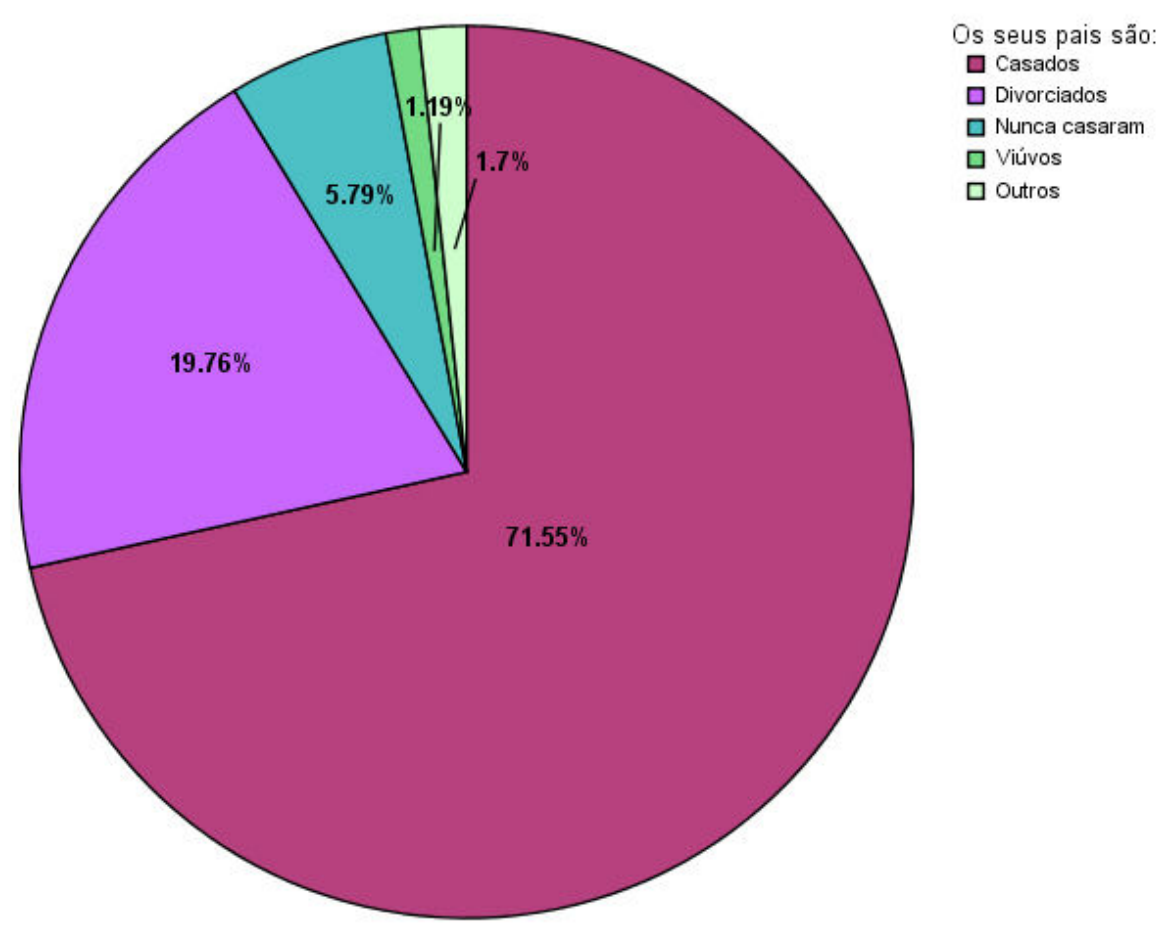

Gráfico 1 - Estado civil dos pais de crianças de escolas privadas 
Nas escolas públicas, verificou-se que $47 \%$ dos pais são casados e $27,2 \%$ são divorciados (as freqüências deste item podem ser verificadas no gráfico 2). No mais, $92,4 \%$ das crianças moram com a mãe enquanto $62,7 \%$ moram com o pai.

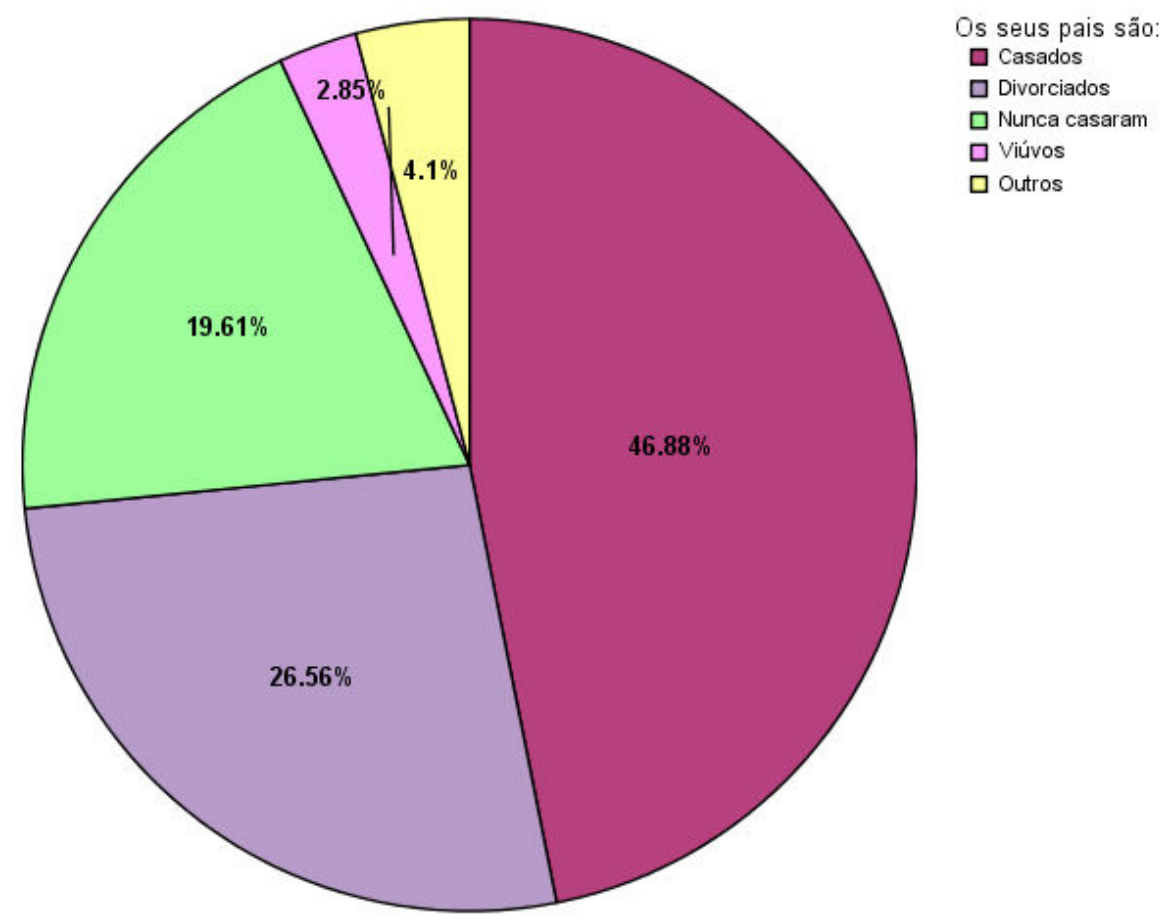

Gráfico 2 - Estado civil dos pais de crianças de escolas públicas

A percentagem de pais que trabalham fora de casa é grande, $97,2 \%$ e $91,4 \%$, respectivamente para pais de crianças de escolas privadas e públicas. A percentagem de mães que trabalham fora é também alta $84,2 \%$ e $81,2 \%$, respectivamente, para crianças de escolas privadas e públicas.

Também foi possível verificar que a maioria dos alunos de escolas públicas e privadas são brancos, representando $44,4 \%$ e $78,7 \%$, respectivamente (tabela 5). As escolas públicas, no entanto, apresentam um percentual muito maior de alunos negros, $32,4 \%$, contra $6,2 \%$ nas escolas privadas. Soares e Alves (2003, p. 149) reconhecem que "a escola continua sendo um produto social desigualmente distribuído. Desigualdades no ingresso aos diferentes tipos e níveis de ensino persistem, ainda que se manifestem hoje de forma menos maciça e mais sutil".

Com base nestes resultados apresentados, foi possível caracterizar demograficamente a população pesquisada. A seguir, serão apresentados os resultados encontrados para o fator Insatisfação. 


\subsection{Insatisfação}

O fator insatisfação diz respeito ao sentimento gerado quando a criança é exposta a padrões diferentes dos seus, quando ela exerce a comparação com outras crianças e se sente inferiorizada por não ser igual àquele padrão estipulado. Este fator é composto por 6 itens, apresentados no quadro 1.

\begin{tabular}{|l|l|}
\hline \multicolumn{1}{|c|}{$\begin{array}{c}\text { Identificação do } \\
\text { item }\end{array}$} & \multicolumn{1}{|c|}{ Afirmação } \\
\hline IN1 (item 1) & $\begin{array}{l}\text { Sinto-me como se as outras crianças tivessem mais coisas } \\
\text { do que eu }\end{array}$ \\
\hline IN2 (item 3) & $\begin{array}{l}\text { Gostaria que minha família pudesse comprar mais daquilo } \\
\text { que desejo }\end{array}$ \\
\hline IN3 (item 6) & Tenho quase tudo de que preciso em termos de posse \\
\hline IN4 (item 8) & $\begin{array}{l}\text { Gostaria que meus pais me dessem mais dinheiro para } \\
\text { gastar }\end{array}$ \\
\hline IN5 (item 12) & Gostaria que meus pais ganhassem mais dinheiro \\
\hline IN6 (item 13) & $\begin{array}{l}\text { Quando escolho meus amigos, não me preocupo com os } \\
\text { brinquedos ou objetos que eles possuem }\end{array}$ \\
\hline
\end{tabular}
Quadro 1 - Itens do fator Insatisfação

A primeira afirmativa do questionário sobre insatisfação dizia: sinto-me como se as outras crianças tivessem mais coisas do que eu (IN1), e os resultados obtidos foram: $74,7 \%$ das crianças que estudam em escolas privadas discordam ou discordam fortemente da afirmação, enquanto, 80,9 \% das crianças de escolas públicas escolheram estas opções. Já no que diz respeito às opções concordo e concordo fortemente, $25,4 \%$ das crianças de escolas privadas e $19,1 \%$ das crianças de escolas públicas escolheram estas opções. A ANOVA realizada demonstrou que existe diferença neste item do fator insatisfação entre crianças de escolas públicas e privadas, sendo a insatisfação maior para as crianças de escolas privadas, apresentando significância. O gráfico 3 apresenta as freqüências de respostas para o primeiro item do fator insatisfação para escolas privadas e públicas. 


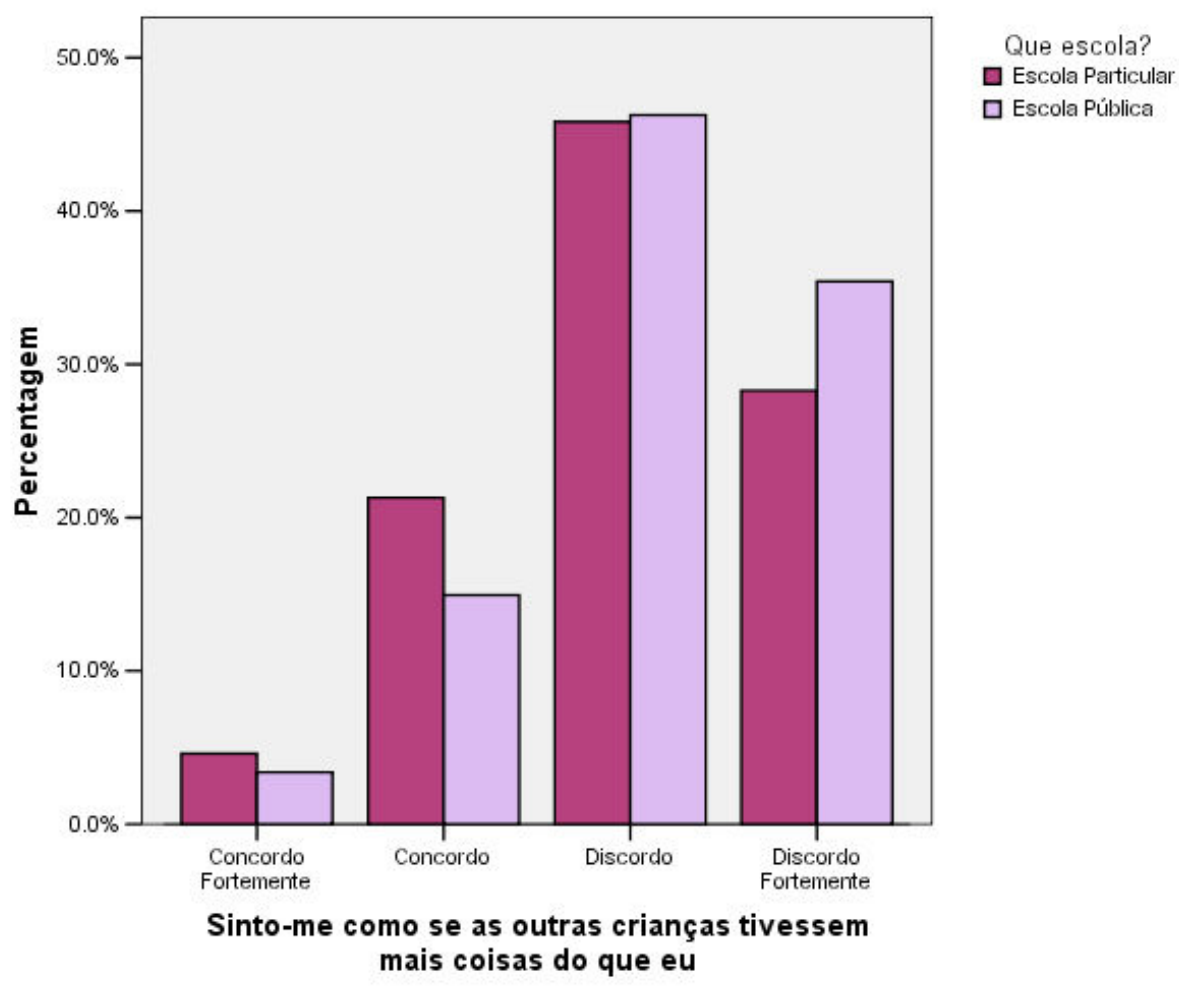

Gráfico 3 - Freqüência de respostas do item IN1

Uma vez que os índices de freqüências que discordaram e discordaram fortemente do item foram altos, supõe-se que as crianças não se sentem diferentes dos pares e talvez por isso a grande maioria dessas crianças afirmem em outra questão (IN3) que possuem quase tudo de que precisam em termos de posse, concordando ou concordando fortemente com esta afirmação, sendo $79,3 \%$ nas escolas privadas e $78,8 \%$ nas escolas públicas. Schor (2004) afirma que as crianças se preocupam muito com a opinião de seus pares. Valkenburg e Cantor (2001) também reforçam essa importância atribuída à opinião dos colegas. É provável que por terem como base de comparação crianças muito parecidas consigo mesmas, e estarem satisfeitas com o que possuem, as crianças demonstrem que não sentem possuir menos do que as outras, visto que, na igualdade do ambiente, acredita-se que todas possuem coisas iguais ou parecidas. Não foi possível identificar diferenças entre as crianças de escolas públicas e privadas, visto que a probabilidade de erro na rejeição da hipótese nula foi alta $(\operatorname{sig}=0,928)$.

O gráfico 4 apresenta as freqüências de respostas para o terceiro item do fator insatisfação para escolas privadas e públicas. 


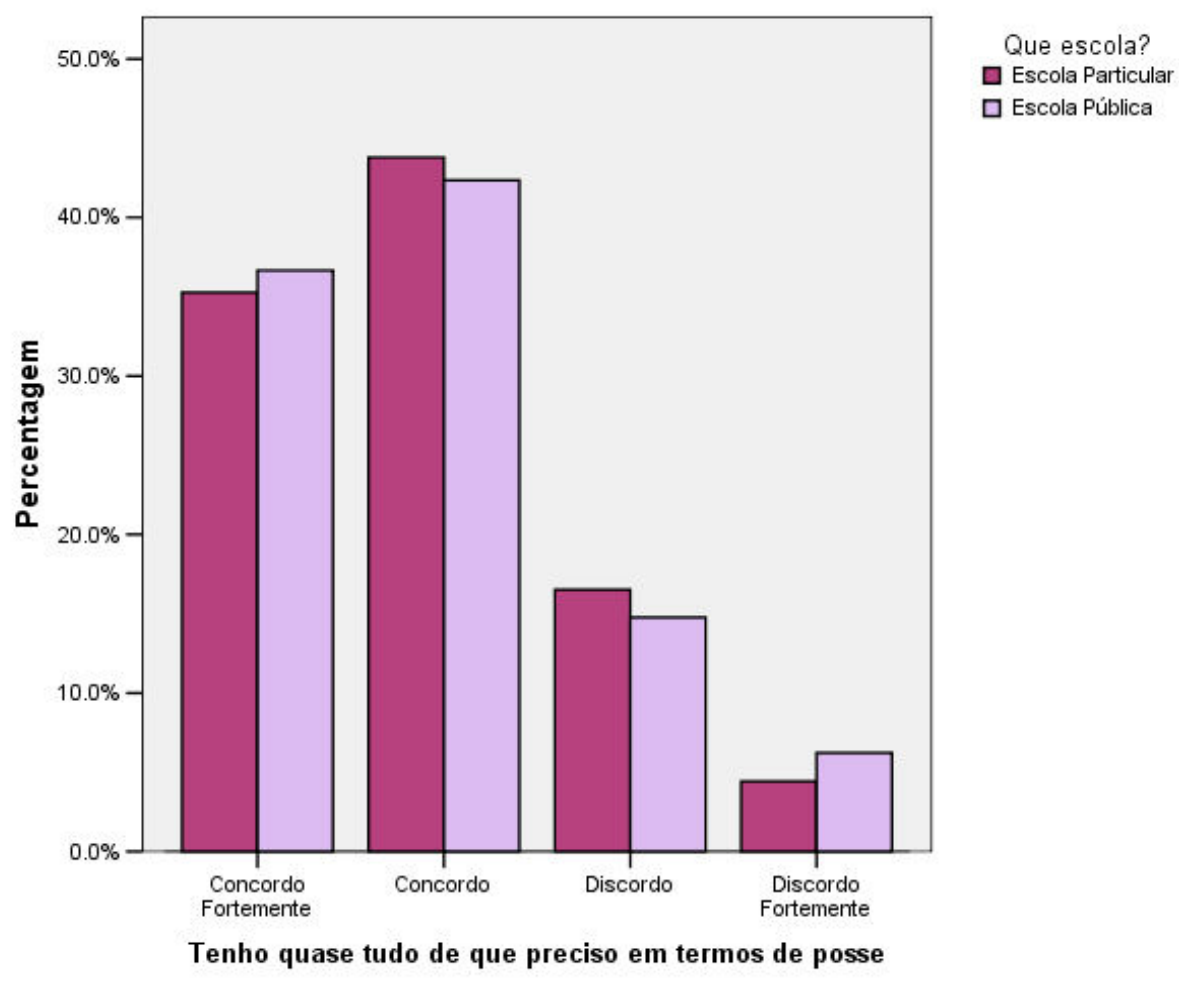

Gráfico 4 - Freqüência de respostas do item IN3

No entanto, ao serem expostas à afirmação de que gostariam que a família pudesse comprar mais daquilo que desejam (IN2), 44,4\% das crianças de escolas privadas e $56 \%$ das crianças de escolas públicas assinalaram as opções concordo fortemente e concordo. Na ANOVA realizada, obteve-se significância (sig=0,000), confirmando a existência de diferença entre os níveis de insatisfação em crianças de escolas públicas e privadas, sendo maior para as crianças de escolas públicas. As freqüências de resposta deste item podem ser vistas no gráfico 5. 


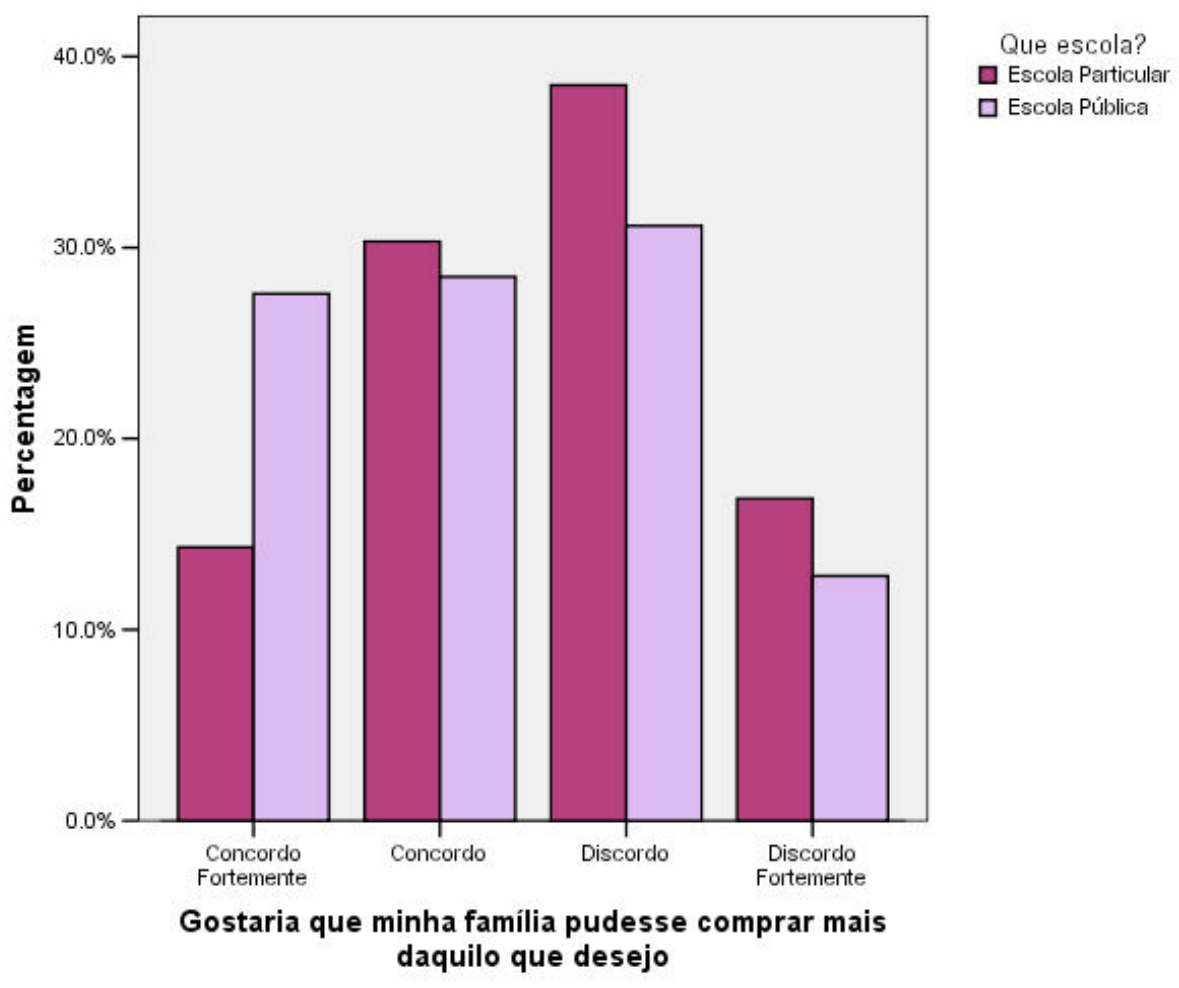

Gráfico 5 - Freqüência de respostas do item IN2

O mesmo resultado pôde ser verificado na afirmação gostaria que meus pais me dessem mais dinheiro para gastar (IN4), quando 49,6\% das crianças de escolas privadas afirmaram concordar ou concordar fortemente com a afirmação e 65,1\% das crianças de escolas públicas marcaram estas mesmas opções, apresentando significância (sig $=0,000$ ) como na questão anterior, confirmando a existência de diferença entre os níveis de insatisfação nas crianças, sendo maior para as crianças de escolas públicas. Esse forte interesse demonstrado pelas crianças em ganhar mais dinheiro suporta a afirmação de McNeal (2000) de que este é certamente um grande público consumidor, que freqüentemente efetua compras. A solicitação por mais dinheiro demonstra uma necessidade destas crianças em satisfazer cada vez mais seus desejos de consumidoras. Mesmo porque, equipamentos eletrônicos e equipamentos para esporte, os itens de maior interesse da faixa etária pesquisada, segundo Valkenburg e Cantor (2001), são produtos de maior custo do que os rotineiros lanches no colégio e cinema priorizados por crianças menores. O gráfico 6 apresenta as freqüências de respostas para o quarto item do fator insatisfação para crianças de escolas privadas e públicas. 


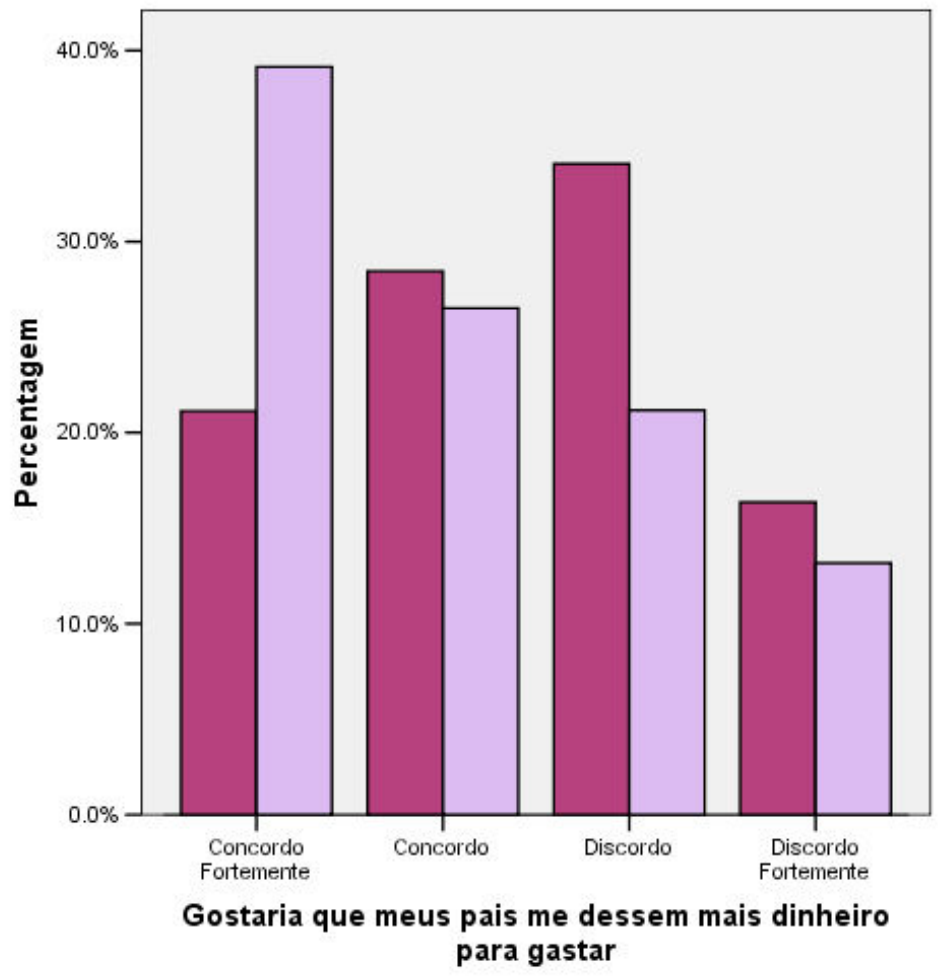

Que escola?

$\square$ Escola Particular

口 Escola Pública

Gráfico 6 - Freqüência de respostas do item IN4

As crianças expressaram também que gostariam que seus pais ganhassem mais dinheiro (IN5), sendo que $56 \%$ das crianças de escolas privadas concordaram fortemente ou concordaram com a afirmação, enquanto $83,1 \%$ das crianças de escolas públicas escolheram estas opções. O alto índice pode ser entendido uma vez que as crianças entendem que o dinheiro que elas recebem virá dos pais, e que se seus responsáveis ganharem mais, existirá a possibilidade de que elas também ganhem. Embora tanto as crianças de escolas públicas quanto as de escola privada expressem esse desejo de que os pais ganhem mais dinheiro, a concordância com o item entre as crianças de escolas públicas foi $27 \%$ maior que entre as crianças de escolas privadas (o gráfico 7 apresenta as freqüências de resposta para este item) e a ANOVA comprovou que a diferença entre os meios existe sim, sendo maior para as crianças de escolas públicas. 


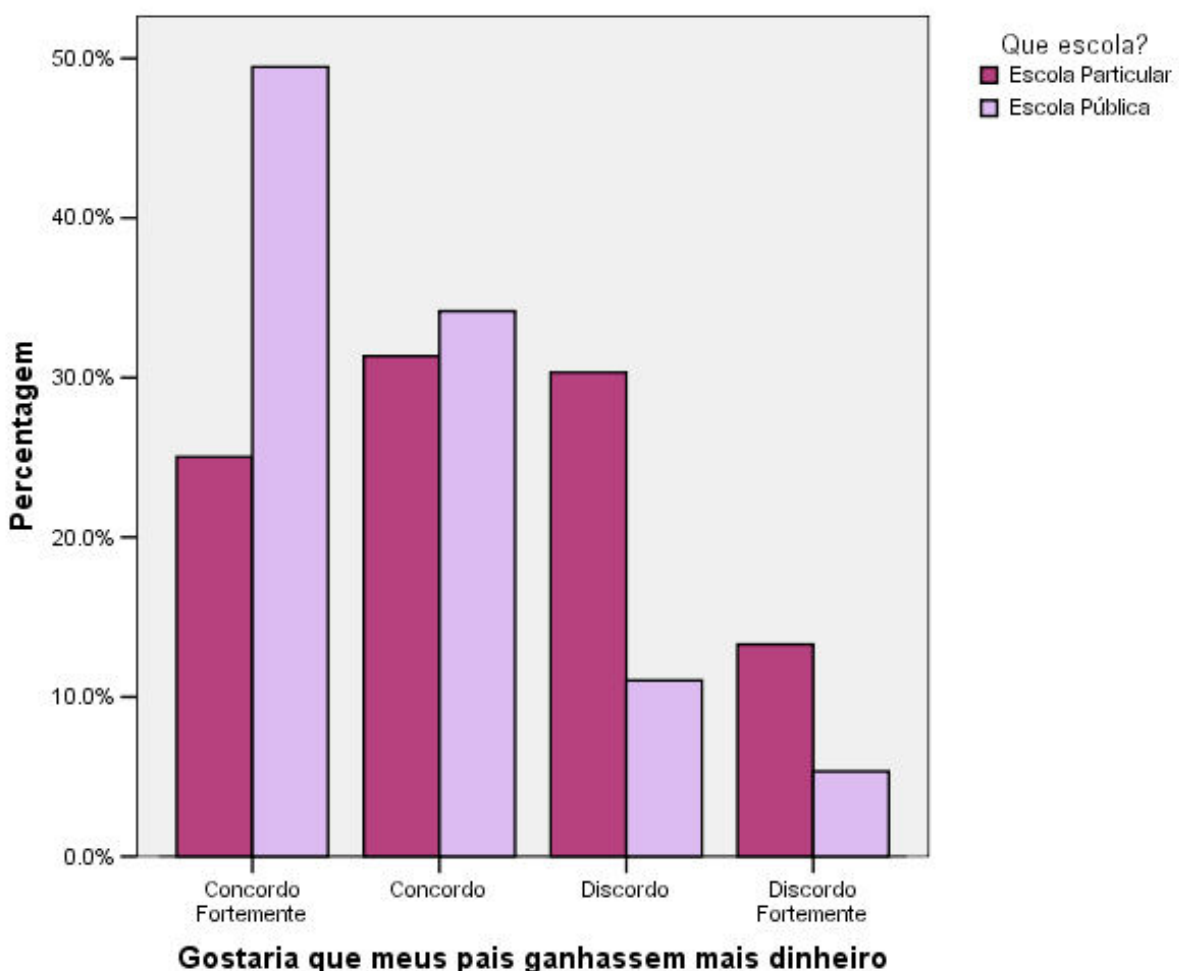

Gráfico 7 - Freqüência de respostas do item IN5

A última afirmativa que mediu o fator insatisfação foi quando escolho meus amigos, não me importo com os brinquedos ou objetos que eles possuem (IN6), sendo concordo ou concordo fortemente os itens mais escolhidos pelas crianças de ambas as escolas. Estas opções representam $93,8 \%$ das respostas nas escolas privadas e $86,4 \%$ nas escolas públicas. Este resultado demonstra que as crianças não são interesseiras quando se trata de buscar novas amizades. A ANOVA realizada demonstrou que existe diferença no fator insatisfação entre crianças de escolas públicas e privadas, sendo maior para as crianças de escolas privadas, apresentando significância ( $\mathrm{sig}=0,000$ ). De acordo com Hartup (1992), as crianças gostam de fazer coisas juntas, se divertem e se importam umas com as outras. Para o autor, embora as crianças em idade escolar não usem palavras como empatia e intimidade para fazer uma descrição de seus amigos, no pensamento destas crianças são esses construtos que distinguem quem são seus amigos. Assim, é possível imaginar porque as posses materiais não são fundamentais para essas crianças, tendo em vista que o que eles buscam verdadeiramente em suas amizades são pessoas que os entendam e os completem, que sejam leais e que eles possam confiar. 
No gráfico 8, é possível observar a freqüência de respostas das crianças de escolas públicas e privadas no item 6 do fator insatisfação.

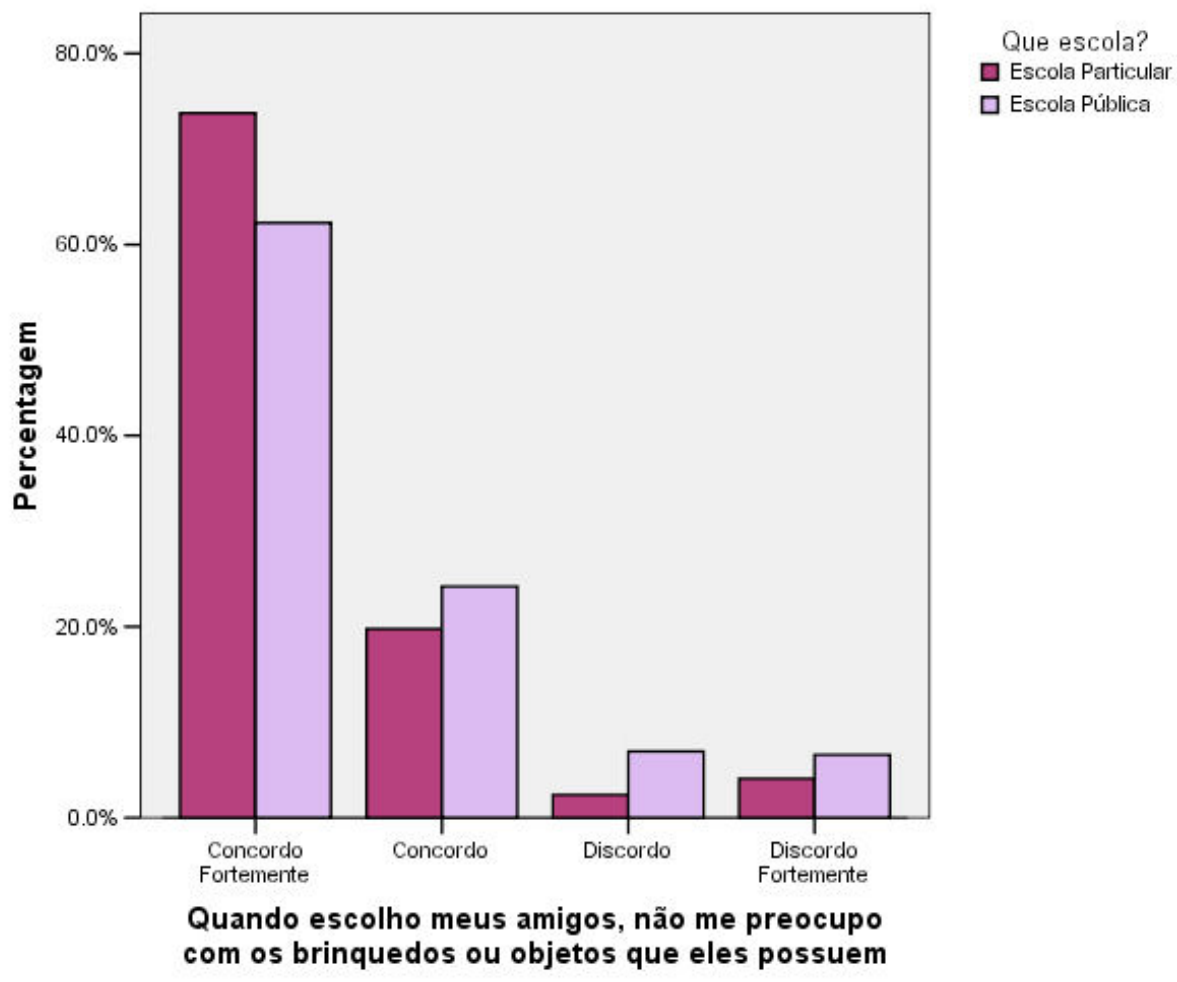

Gráfico 8 - Freqüência de respostas do item IN6

A seguir, serão apresentados os resultados encontrados para o fator Orientação do consumidor.

\subsection{Orientação do consumidor}

A orientação do consumidor diz respeito ao comportamento do consumidor. No instrumento utilizado, este fator foi composto por cinco itens, conforme apresenta o quadro 2.

\begin{tabular}{|l|l|}
\hline $\begin{array}{c}\text { Identificação do } \\
\text { item }\end{array}$ & \multicolumn{1}{|c|}{ Afirmação } \\
\hline OC1 (item 7) & $\begin{array}{l}\text { Sempre tenho algo em mente que quero comprar ou } \\
\text { conseguir }\end{array}$ \\
\hline OC2 (item 9) & Quero ter muito dinheiro quando crescer \\
\hline OC3 (item 10) & $\begin{array}{l}\text { Preocupo-me muito com meus brinquedos, jogos e outros } \\
\text { objetos }\end{array}$ \\
\hline OC4 (item 11) & Gosto de comprar e ir às lojas \\
\hline OC5 (item 15) & $\begin{array}{l}\text { Quando vou a algum lugar especial, normalmente compro } \\
\text { alguma coisa }\end{array}$ \\
\hline
\end{tabular}

Quadro 2 - Itens do fator Orientação do Consumidor 
O primeiro item do questionário proposto a medir esse fator foi sempre tenho em mente algo que quero comprar ou conseguir (OC1). Os resultados evidenciaram que $71,2 \%$ das crianças de escolas privadas e $83,8 \%$ das crianças de escolas públicas dizem que concordam ou concordam fortemente com a afirmação, destacando o desejo por consumo destas crianças. Essa é uma evidência do porquê apenas 39\% das crianças, segundo o estudo Kids Power - Poder das crianças (2007), guardam o dinheiro que recebem. Valkenburg e Cantor (2001) reforçam que esses desejos e preferências que as crianças expressam fazem parte das características do comportamento do consumidor, e McNeal (1979) lembra que desde os 4 e 5 anos as crianças já estão treinando para serem consumidoras, e que dos 7 aos 12 anos de idade, as compras freqüentemente serão feitas. O Kids Power - Poder das crianças (2007) demonstrou também que um grande número de crianças recebe dinheiro dos pais, podendo, desta forma, exercer diretamente o poder de compra. Ao passo em que compram e possuem informações para comprar, as ambições tornam-se maiores.

Schor (2004) salienta que a cada visita que as crianças fazem a lojas, compram cerca de 6 itens, justificando a alta percentagem de crianças que afirma possuir sempre algo em mente que quer comprar ou conseguir. Foi possível constatar ainda por meio da ANOVA a existência de diferença entre os níveis de orientação do consumidor em crianças de escolas públicas e privadas, sendo maior para as crianças de escolas públicas, uma vez que a probabilidade de erro na rejeição de $\mathrm{H}_{0}$ foi muito baixa (sig=0,000).

As freqüências de respostas para o primeiro item do fator orientação do consumidor podem ser observadas no gráfico 9 . 


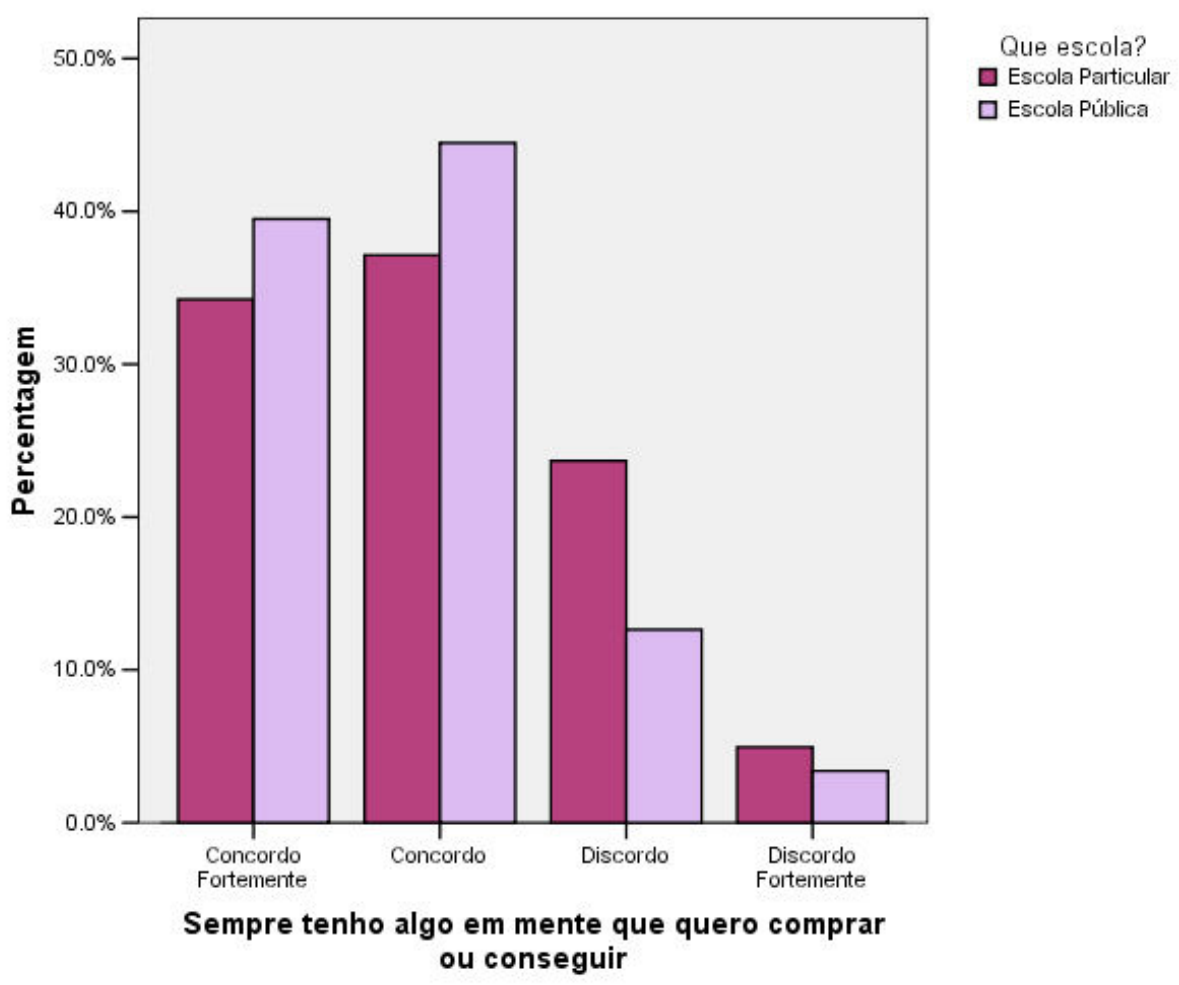

Gráfico 9 - Freqüência de respostas do item OC1

Outro item existente no questionário afirmava quero ter muito dinheiro quando crescer (OC2). Um número realmente grande de crianças afirma que concorda fortemente com a afirmação, sendo $54,4 \%$ nas escolas privadas e $65,7 \%$ nas escolas públicas. Esse número cresce se levada em consideração a percentagem de crianças que dizem concordar com o que foi dito. Evidencia-se então um percentual de $91 \%$ para crianças de escolas privadas e $92,6 \%$ para as de escola pública, um número que realmente chama a atenção (a freqüência de respostas obtidas neste segundo item do fator orientação do consumidor podem ser observadas no gráfico 10). Wulfmeyer e Muller (1992 apud BUIJZEN; VALKENBURG, 2003) explicam que as crianças compreendem a importância do dinheiro, e reconhecem que ele é fundamental para que se comprem bens que proporcionem tudo aquilo que elas desejam em termos de satisfação pessoal. Daí a grande percentagem de crianças que ambiciona a posse de muito dinheiro na vida adulta. McNeal (1979, p. 354) também dá suporte a esses números ao afirmar que as crianças sabem o significado do dinheiro e o entendem como "requisito básico para se obter boas coisas na vida". Mais uma vez, foi possível confirmar a existência de diferença na orientação do consumidor de crianças de escolas públicas e privadas, sendo maior para as crianças de escolas públicas. 


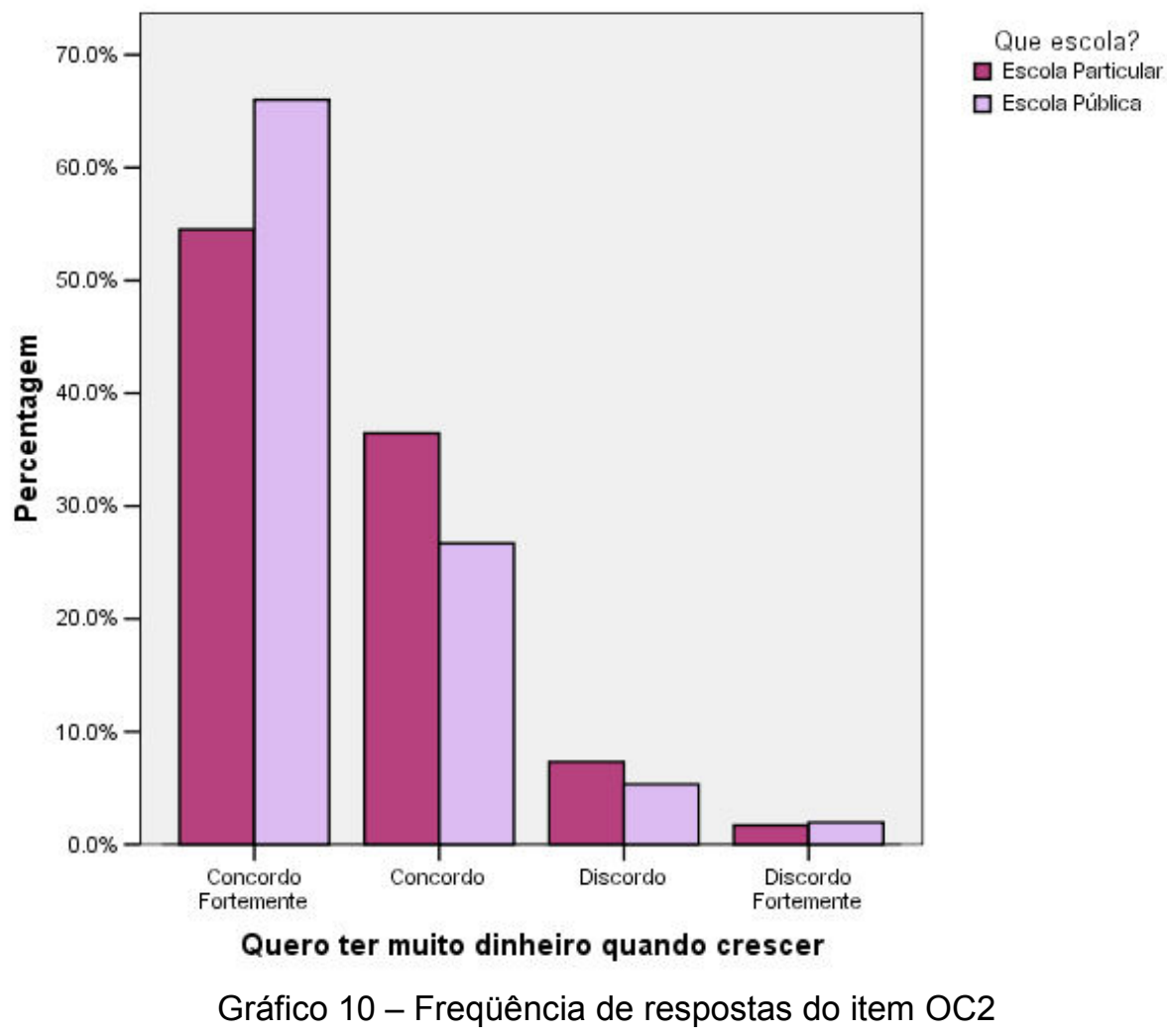

Quando expostas à afirmação preocupo-me muito com meus brinquedos, jogos e outros objetos (OC3), 73,9\% e 79,1\% das crianças de escolas públicas e privadas, respectivamente, disseram concordar ou concordar fortemente. Para Jovchelovitch (2005 apud GROSSI; SANTOS, 2007) os brinquedos são formas de apego da criança. E embora a autora afirme que a sociedade do consumo esteja modificando esta função, os índices encontrados demonstram que as crianças ainda se preocupam com os objetos e brinquedos que possuem, demonstrando que a descartabilidade destacada pela autora possivelmente não se aplique neste caso. Neste item não foi possível a rejeição da hipótese nula, uma vez que a probabilidade de erro em rejeitá-la foi alto $(\mathrm{sig}=0,329)$. Achenreiner e John (2003) lembram que o simbolismo é muito importante no processo de socialização das crianças. Assim, o significado de possuir certos produtos ou marcas é fundamental para as crianças e talvez por isso não existam diferenças entre elas neste item, pois aquilo que seus brinquedos, jogos e outros objetos representam para elas seja importante a ponto de todos se preocuparem com a sua manutenção. No gráfico 11, é possível observar a freqüência de respostas das crianças de escolas públicas e privadas para este terceiro item do fator orientação do consumidor. 


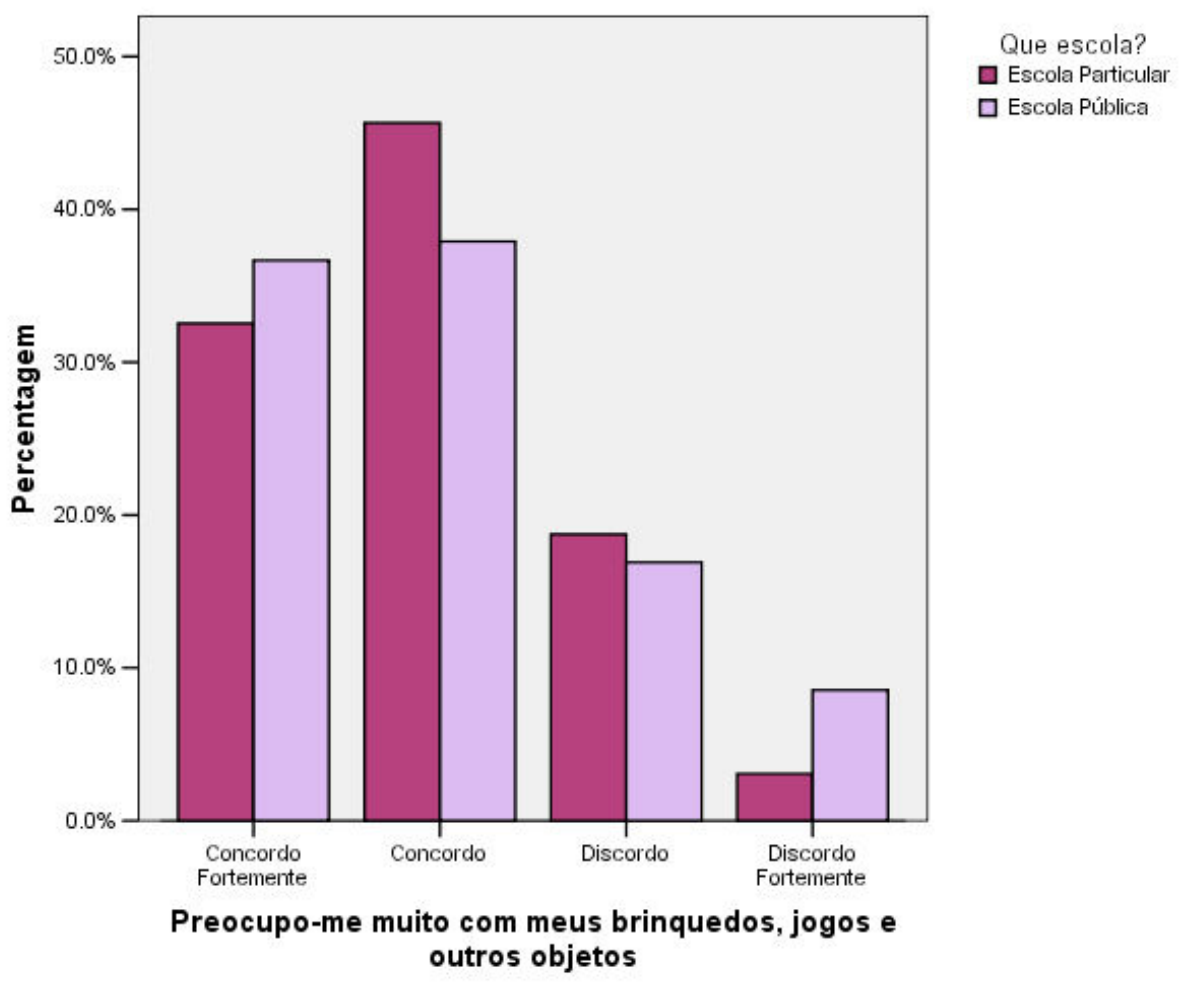

Gráfico 11 - Freqüência de respostas do item OC3

Para McNeal (1979), os pais não se preocupam em esconder o mercado de consumo das crianças e entendem que se tornar consumidor faz parte de um processo natural de crescimento. Quando as crianças responderam sobre a afirmação gosto de comprar e ir às lojas (OC4), foi possível observar que $72,9 \%$ das crianças de escolas privadas e $83,4 \%$ das crianças de escolas públicas afirmam concordar ou concordar fortemente com a afirmação. Corroborando com o resultado encontrado, Schor (2004) lembra que as crianças de 6 a 12 anos de idade visitam lojas duas a três vezes por semana e compram sempre algum item durante estas visitas. Além disso, a autora afirma que a relação das crianças como consumidoras existe há tempos, pois produtos destinados a este público existem há séculos. McNeal (1979) afirma que desde os 5 anos as crianças realizam compras, e habituam-se a este universo. Assim, não se pode dizer que o resultado apresentado foi inesperado, uma vez que todas as evidências apontavam para uma orientação voltada para o consumo. Foi possível demonstrar a existência de diferença entre os níveis de orientação do consumidor em crianças de escolas públicas e privadas, sendo maior para as crianças de escolas públicas, dando suporte a Furnham (2001 apud LAURINDO; LEAL, 2008) que afirma que o fator social pode afetar os hábitos de consumo de um indivíduo. Cabe ressaltar, contudo, que o autor afirma que 
crianças mais pobres terão uma aprendizagem de consumo diferente, visto que não podem consumir como as crianças de classes elevadas.

O gráfico 12 apresenta a freqüência das respostas das crianças de escolas públicas e privadas para o item OC4.

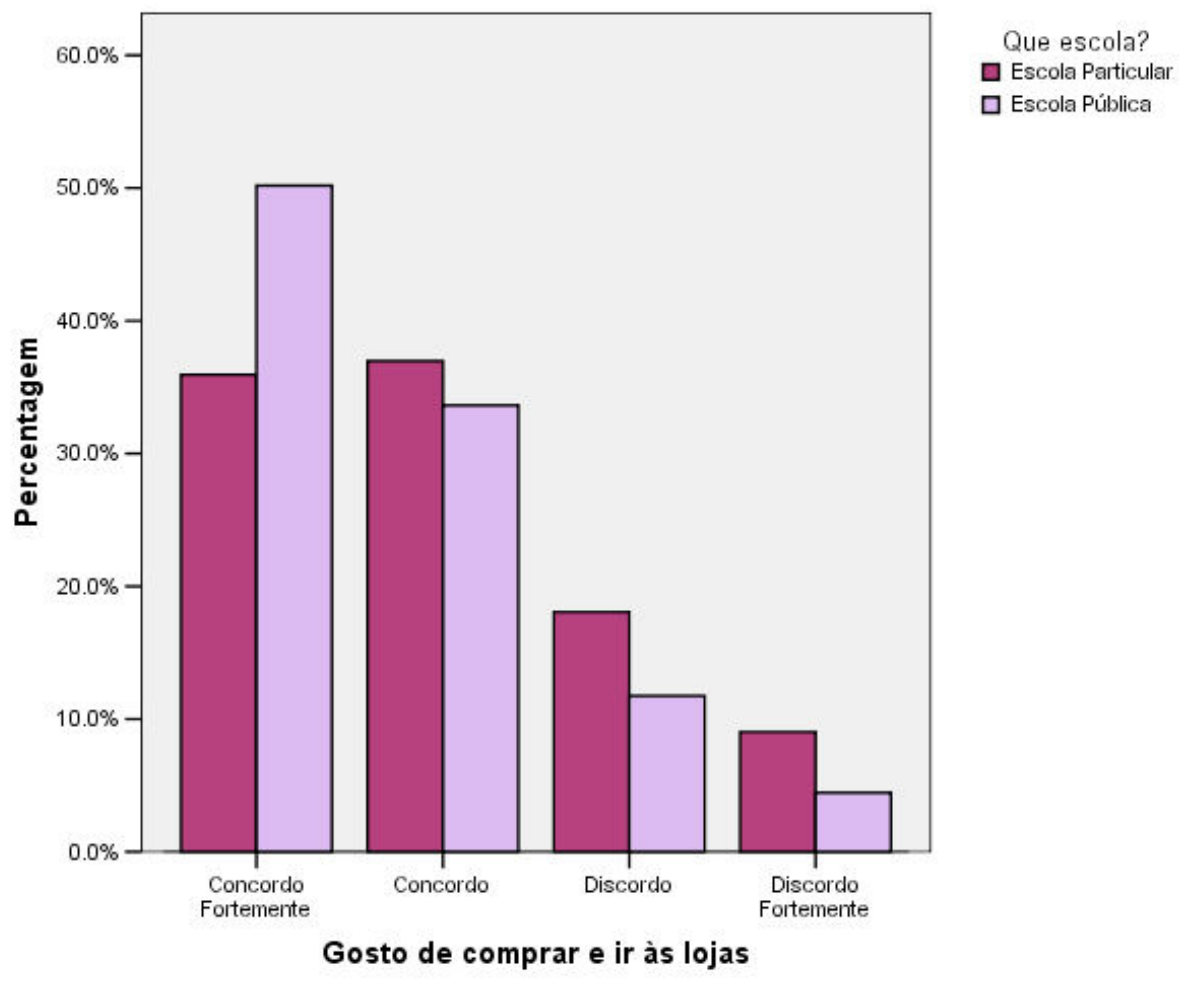

Gráfico 12 - Frequência de respostas do item OC4

Ainda procurando saber sobre compras, o último item do fator orientação do consumidor afirmava quando vou a algum lugar especial normalmente compro alguma coisa (OC5), e constatou-se que 25,5\% das crianças de escolas privadas e $28,1 \%$ das crianças de escolas públicas disseram que concordam fortemente com o item. O índice cresce quando se considera que $43 \%$ e $45,8 \%$ das crianças de escolas privadas e públicas, respectivamente, afirmam concordar com o que foi afirmado (no gráfico 13, é possível observar a freqüência de respostas das crianças de escolas públicas e privadas para este item). Possivelmente, este resultado pode ser explicado pelos motivos já expostos em relação ao item OC4. As crianças estão acostumadas a comprar, é um hábito para elas, e nesta idade, segundo McNeal (1979) elas já compram produtos para si e para os outros, sendo o papel de consumidor rotineiro. Strasburger (2004) afirma que o gasto anual de crianças abaixo dos 12 anos chega a 25 bilhões de dólares, reforçando o quanto o ato de comprar em si é natural para elas. Também neste item verificou-se a existência de 
diferença entre os níveis de orientação do consumidor em crianças de escolas públicas e privadas, sendo maior para as crianças de escolas públicas. Essa diferença entre as crianças pode ser explicada uma vez que para Page e Ridgway (2001) o ambiente em que as crianças consomem tem influência nos padrões de consumo das pessoas, demonstrando a existência de diferenças nos padrões de consumo entre crianças que vivem em áreas socioeconômicas diferentes.

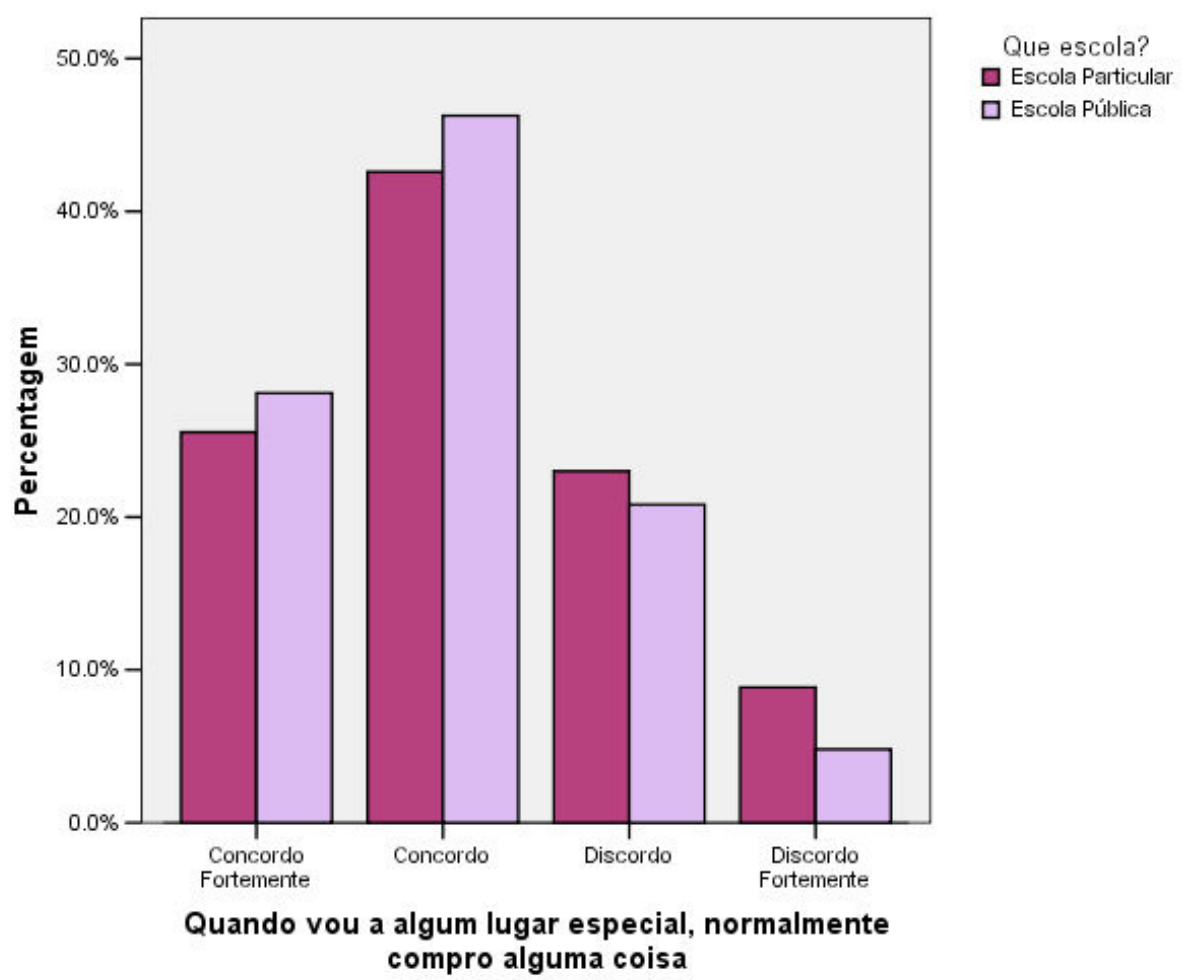

Gráfico 13 - Freqüência de respostas do item OC5 


\subsection{Reconhecimento da marca}

Para a avaliação deste fator foram utilizados 5 itens do questionário. O quadro 3 apresenta a identificação destes itens.

\begin{tabular}{|l|l|}
\hline $\begin{array}{c}\text { Identificação do } \\
\text { item }\end{array}$ & \multicolumn{1}{|c|}{ Afirmação } \\
\hline RM1 (item 2) & Não me preocupo muito com o que visto \\
\hline RM2 (item 4) & $\begin{array}{l}\text { As marcas têm significado pra mim (me importo com as } \\
\text { marcas) }\end{array}$ \\
\hline RM3 (item 5) & $\begin{array}{l}\text { Não me importo com o tipo de carro que a minha família } \\
\text { possui }\end{array}$ \\
\hline RM4 (item 14) & $\begin{array}{l}\text { Gosto de roupas com etiquetas reconhecidas (gosto de } \\
\text { roupas de marca) }\end{array}$ \\
\hline RM5 (item 16) & Ser "cool" (maneiro, legal) é importante pra mim \\
\hline \multicolumn{2}{|c|}{ Quadro 3 - Itens do fator Reconhecimento da Marca } \\
\hline
\end{tabular}

A primeira afirmação buscou identificar a relação das crianças com o que vestem, ao dizer não me preocupo muito com o que visto (RM1). O resultado demonstrou que $69,2 \%$ das crianças de escolas privadas disseram discordar ou discordar fortemente da afirmação, enquanto $66,2 \%$ das crianças de escolas públicas assinalaram estas mesmas opções, demonstrando que sim, as crianças se preocupam com o que vestem. Valkenburg e Cantor (2001) já afirmavam que a faixa etária estudada neste trabalho passa por um período onde seu olhar crítico se desenvolve, e eles estão mais atentos aos detalhes e à qualidade dos produtos. É também nesta idade que as crianças passam a avaliar criticamente e a comparar produtos e informações e uma vez que a opinião dos colegas e amigos é de fundamental importância, eles prestam muita atenção em como se comportam perante os outros, pois não desejam ser ridicularizados. Neste processo, as roupas são um elemento fundamental.

Para McNeal (1979) já a partir dos 7 anos de idade, itens de vestuário passam a fazer parte das compras de crianças, demonstrando assim a importância dada desde cedo por eles às roupas. Portanto, o resultado obtido não causa estranhamento. Não foi possível afirmar que há diferenças entre as crianças de escolas públicas e privadas no que tange à preocupação com o que vestem, uma vez que a probabilidade de erro na rejeição da hipótese foi alta (sig=0,364). 0 resultado pode ser explicado em virtude de a vestimenta ser um item básico para todas as crianças, independente da classe socioeconômica à qual pertencem, e o fato de se preocuparem com a opinião dos colegas faz com que as crianças estejam 
atentas ao que vestem, pois suas roupas e acessórios são um modo de buscarem externalizar suas personalidades, buscando afirmação e aceitação. O gráfico 14 apresenta a freqüência de respostas das crianças de escolas públicas e privadas para o primeiro item do fator reconhecimento da marca.

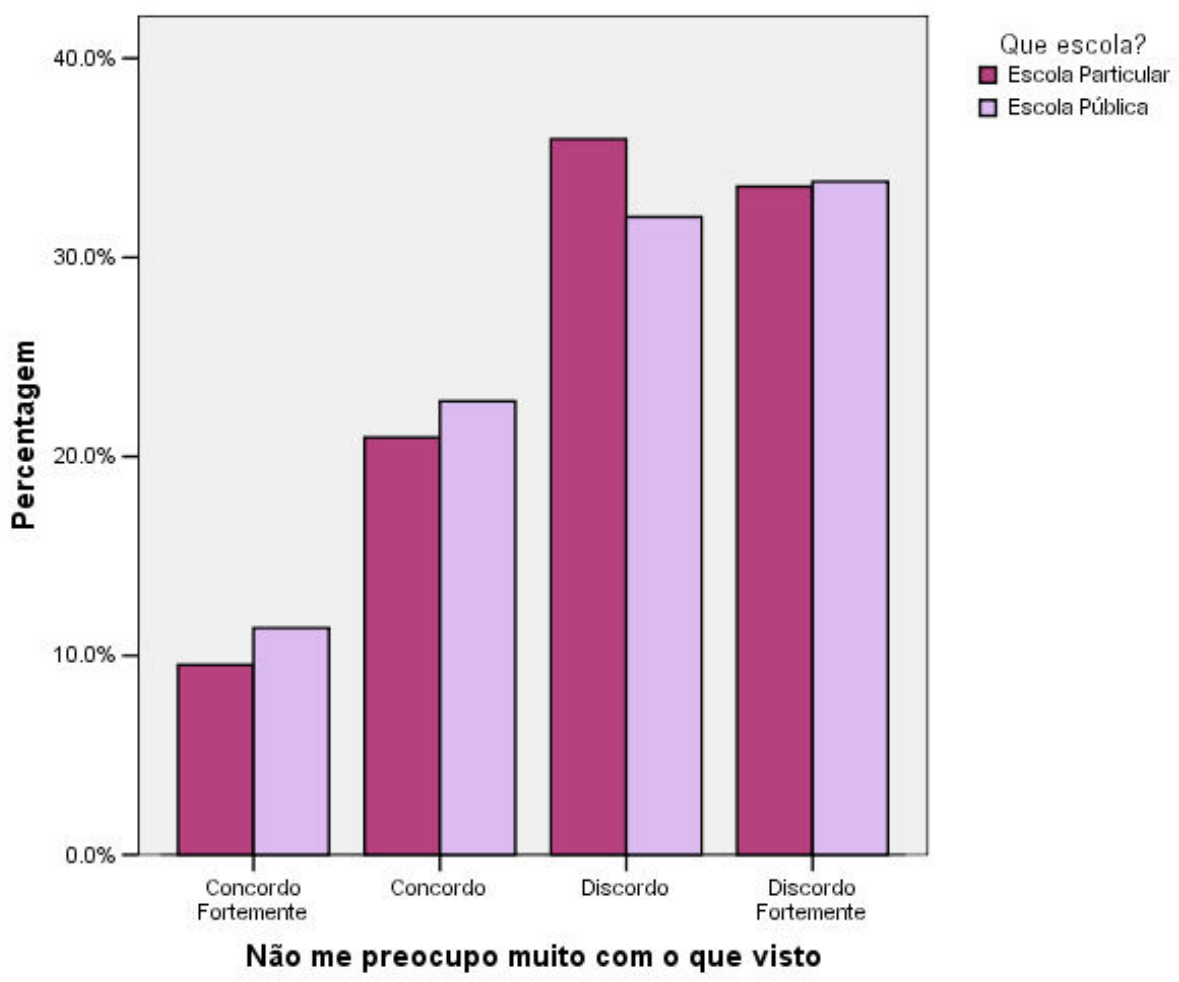

Gráfico 14 - Freqüência de respostas do item RM1

Já em outro item analisado e relacionado com roupas, avaliou-se a importância da marca, na afirmação gosto de roupas com etiquetas reconhecidas (gosto de roupas de marca) (RM4). Constatou-se que 55,3\% das crianças de escolas privadas e $64 \%$ das crianças de escolas públicas afirmaram concordar ou concordar fortemente com a afirmação. Isso demonstra que não só as crianças se preocupam com o que vestem como se preocupam com a marca que os veste. Achenreiner e John (2003) já haviam dito que os jovens da atualidade se destacam pela maior consciência de marcas, uma vez que possuem maior conhecimento e preferências por marcas específicas. Para as autoras, à medida em que as crianças crescem, cresce também a importância que elas dão às marcas. As autoras salientam também que por volta dos 11 - 12 anos de idade, as crianças formam impressões sobre os donos de produtos baseados nas marcas e nos significados das marcas identificadas nos usuários, demonstrando assim porque as crianças dão tanta importância à marca da roupa que vestem. Neste item, a probabilidade de erro na rejeição da hipótese nula 
foi baixíssimo (sig=0,000), confirmando a existência de diferença entre os níveis de preferência por etiquetas reconhecidas entre crianças de escolas públicas e privadas, sendo maior para as crianças de escolas públicas. No gráfico 15 , é possível observar a freqüência de respostas das crianças para o item RM4.

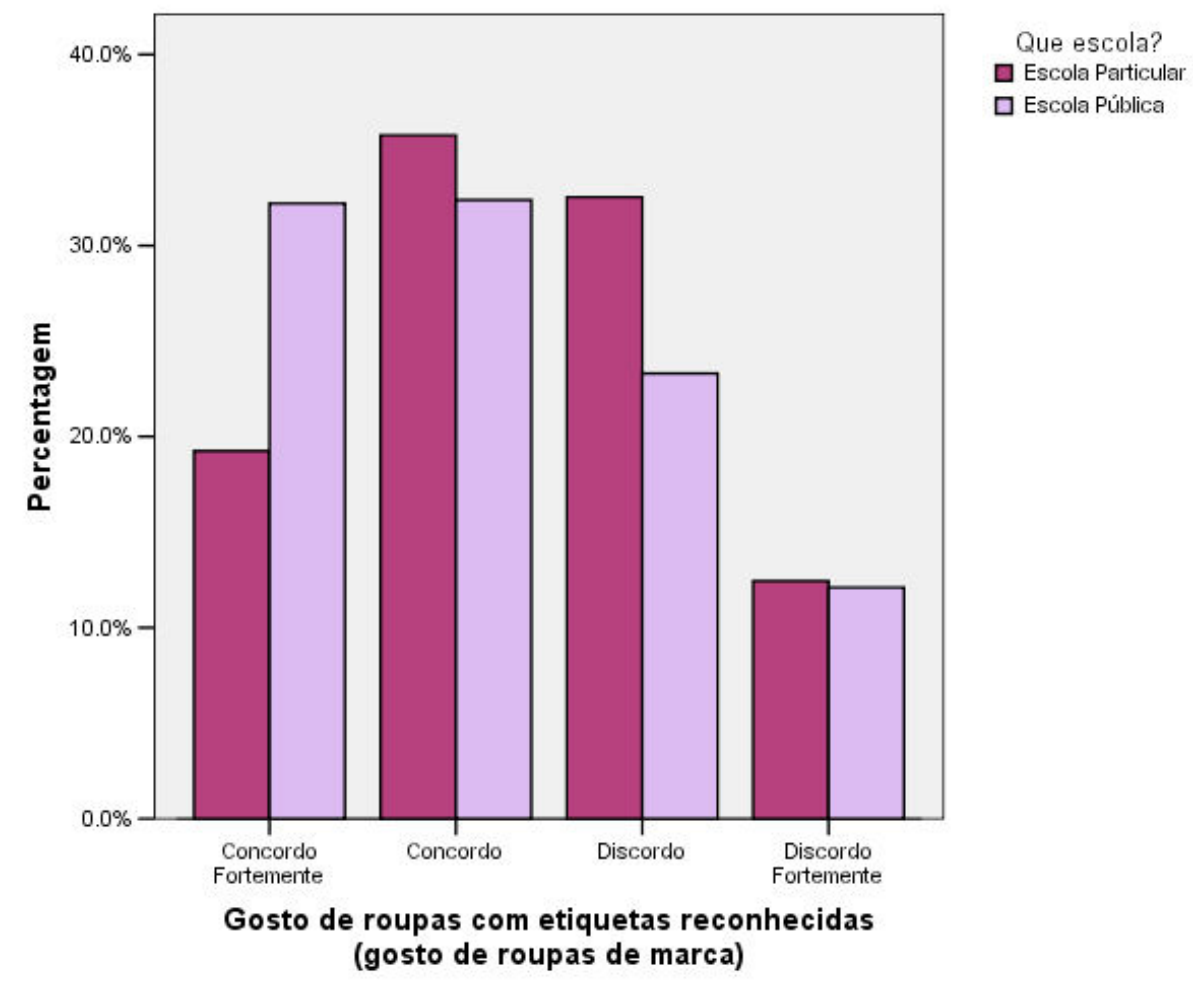

Gráfico 15 - Freqüência de respostas do item RM4

Outro item a investigar a relação das crianças com as marcas buscava entender a importância delas para as crianças ao afirmar as marcas têm significado para mim (me importo com as marcas) (RM2), e os resultados encontrados mostraram que $15,1 \%$ das crianças de escolas privadas concordam fortemente, ao passo que, mais que o dobro deste valor, $31,2 \%$ das crianças de escolas públicas escolheram este item. Este número torna-se menos discrepante quando se considera que $34,7 \%$ das crianças de escolas privadas assinalaram concordar com a afirmação, enquanto $25 \%$ das crianças de escolas públicas também marcaram concordar com o que foi dito. A percentagem de crianças que disseram discordar ou discordar fortemente da afirmação nas escolas privadas somou $50,1 \%$, um número muito próximo à percentagem de crianças que disseram concordar ou concordar fortemente $(49,8 \%)$. Já nas escolas públicas, $43,9 \%$ disseram discordar ou discordar fortemente enquanto $56,2 \%$ afirmaram concordar ou concordar fortemente. 
O resultado encontrado nas escolas privadas parece ser um pouco inesperado, uma vez que no ambiente escolar foi possível observar que as crianças em sua esmagadora maioria possuíam objetos, como mochilas, de praticamente uma única marca, assim como bolsas, estojos e cadernos. É difícil entender que crianças que possuem itens tão parecidos, quase iguais, não se importem com as marcas dos pertences que ostentam.

Já as crianças de escolas públicas, ao responderem este item, por diversas vezes falavam em voz alta o nome de inúmeras marcas, de diferentes áreas de consumo, expressando o quão importante era a posse de determinado bem de marca. Isso vai ao encontro do que Ross e Harradiner (2004) descobriram em sua pesquisa com crianças de 9 a 11 anos que afirmavam preferir produtos falsificados que parecessem reais, do que ter produtos de marcas desconhecidas.

Mais uma vez foi confirmada a diferença entre as crianças de escolas públicas e privadas, visto que o item medido apresentou significância, sendo o reconhecimento da marca maior em crianças de escolas públicas. No gráfico 16 é possível observar a freqüência de respostas para o segundo item do fator reconhecimento da marca.

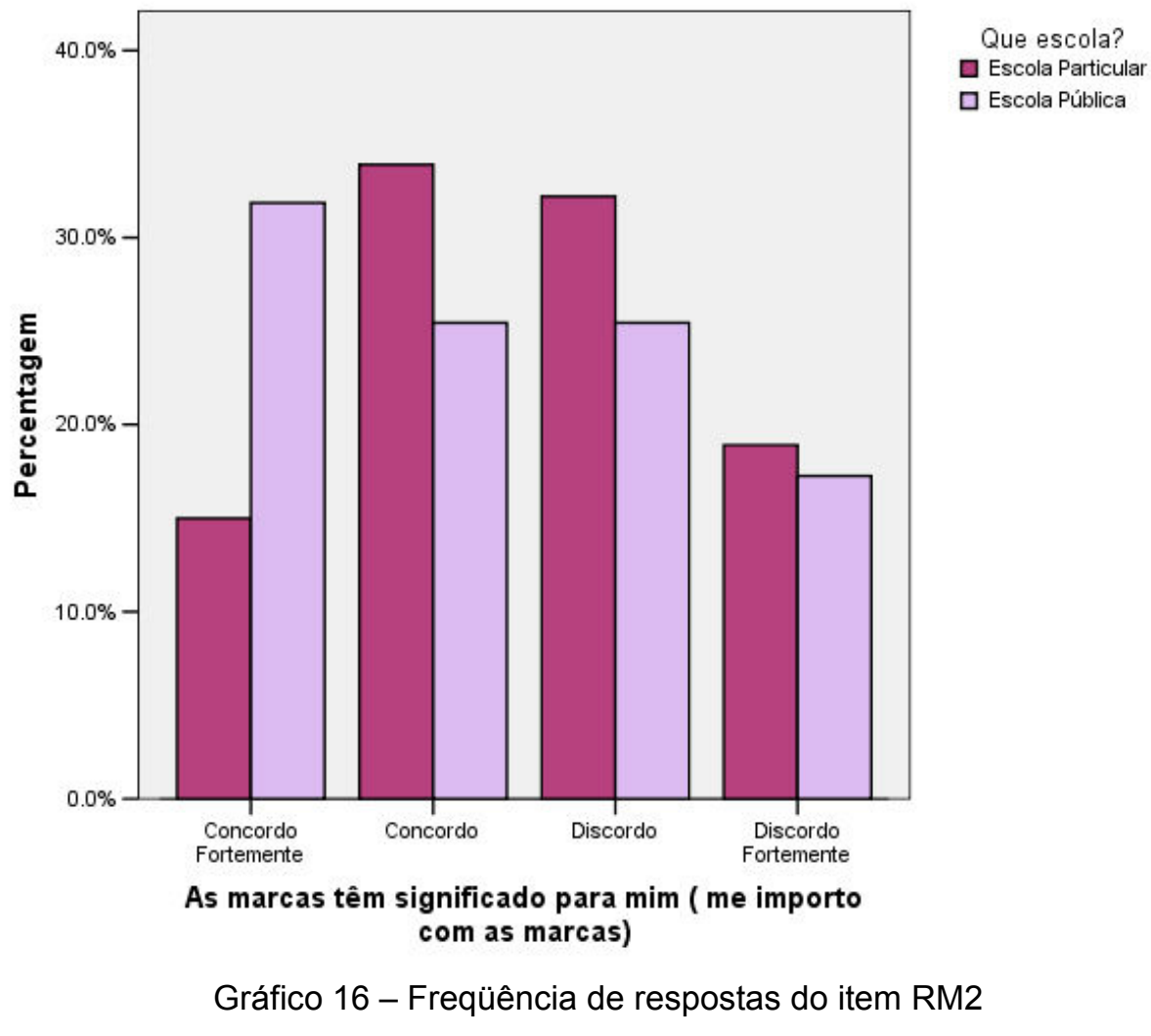

O terceiro item deste fator buscou relacionar a importância para as crianças dos veículos pertencentes às famílias ao afirmar não me importo com o tipo de carro que 
a minha família possui (RM3). As respostas dadas pelas crianças mostraram que $25,9 \%$ daquelas que estudam em escolas privadas e $26,2 \%$ das que estudam em escolas públicas concordam fortemente, enquanto $34,7 \%$ das que estudam em escolas privadas e $38,9 \%$ das que estudam em escolas públicas afirmaram concordar com o item (no gráfico 17, é possível observar a freqüência de respostas das crianças de escolas públicas e privadas para o item RM3).

$\mathrm{Na}$ Análise de Variância não foi possível rejeitar a hipótese nula, visto que a probabilidade de erro em sua rejeição é muito alta, ( $(\mathrm{ig}=0,956)$, o que indica similaridades no que diz respeito à importância dada pelas crianças de escolas públicas e privadas à marca do carro que a família possui.

McDougall e Chantrey (2004), em pesquisa realizada com crianças de 9 a 14 anos, mostram que $59 \%$ das crianças no Brasil afirmam que os responsáveis solicitam a sua opinião para comprarem um carro. Considerando que esta percentagem corresponde a mais da metade dos responsáveis, é estranho constatar que as crianças não se importem com a marca do carro. No entanto, como a compra de um carro não é realizada por crianças e uma vez que elas não o utilizam de maneira direta, pois é um produto cuja finalidade maior não pode ser experimentada por elas, o julgamento que fazem a respeito dos carros é possivelmente relacionado majoritariamente à sua "beleza" e talvez, por isso, as crianças afirmem não se importar com a marca do carro. Além disso, não necessariamente as crianças terão sua imagem associada diretamente ao carro que possuem, daí possivelmente a não preocupação com a escolha do veículo. 


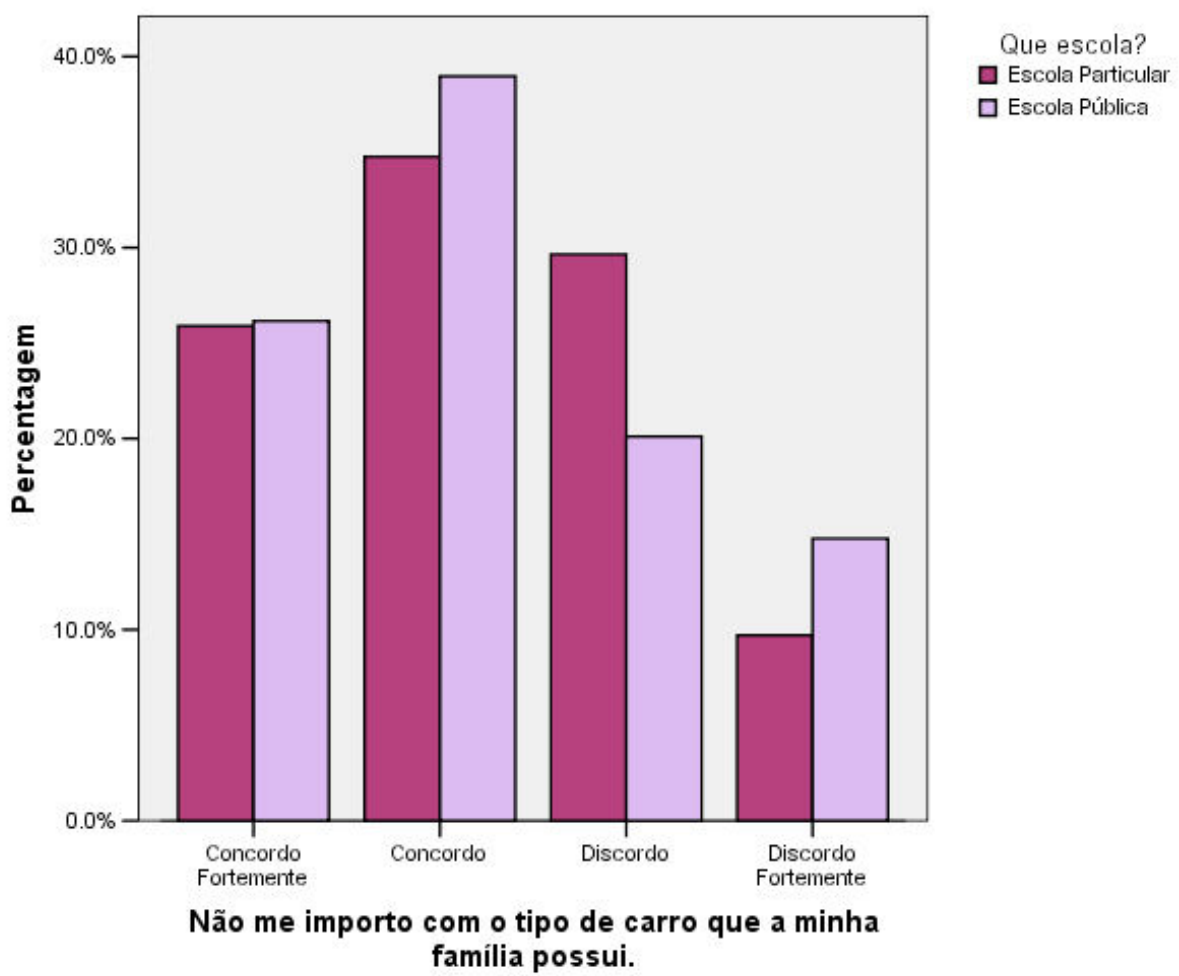

Gráfico 17 - Freqüência de respostas do item RM3

O quinto e último item do fator buscou descobrir a importância que as crianças atribuem à imagem que passam, assim, afirmou que ser "cool" (maneiro, legal), é importante para mim (RM5). O percentual de crianças que afirmaram concordar fortemente foi de $30,5 \%$ nas escolas privadas e $49,9 \%$ nas escolas públicas. As que afirmaram concordar representaram $37,5 \%$ nas escolas privadas e $30,3 \%$ nas escolas públicas, totalizando um percentual de concordo e concordo fortemente de $68 \%$ nas escolas privadas e $80,2 \%$ nas escolas públicas. Este resultado não causa espanto e pode ser explicado facilmente pela necessidade das crianças de se sentirem como parte de um grupo, de serem aprovadas pelos demais.

Valkenburg e Cantor (2001) afirmam que as crianças são muito sensíveis aos pensamentos, opiniões, julgamentos e avaliações de seus pares, tornando-se bastante perceptivas ao que é descolado, legal e moderno. Assim, as marcas são um modo de diferenciação ao mesmo tempo em que assumem a forma de uma igualdade. Diferenciam no momento em que elas afirmam, segundo Schor (2004, p.4), "quem terá amigos e quem não os terá" e igualam a partir do momento em que se integra um grupo de características quase idênticas, onde todos possuem os mesmos objetos, das mesmas marcas, representando o status daquela união. A ANOVA realizada apresentou significância, (sig=0,000), possibilitando afirmar que 
neste caso também existem diferenças no reconhecimento da marca entre crianças de escolas públicas e privadas, sendo novamente maior para crianças de escolas públicas.

No gráfico 18, são apresentadas as freqüências de respostas do item RM5.

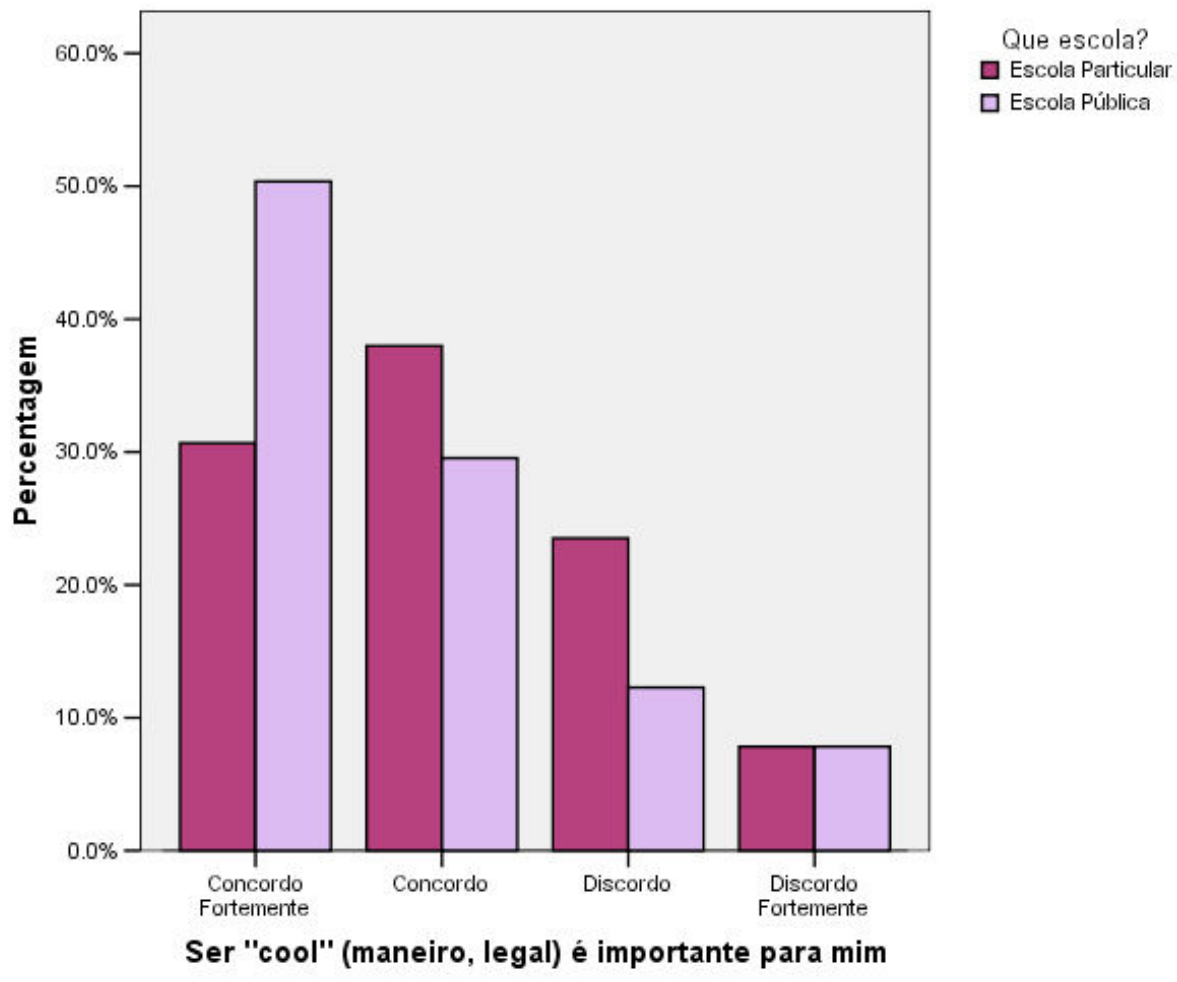

Gráfico 18 - Freqüência de respostas do item RM5

A Tabela 6 resume os resultados encontrados na Análise de Variância realizada nos itens dos fatores Insatisfação, Orientação do Consumidor e Reconhecimento da marca. 
Tabela 6 - ANOVA

\begin{tabular}{|c|c|c|c|c|c|}
\hline & & $\begin{array}{l}\text { Soma dos } \\
\text { quadrados }\end{array}$ & $\begin{array}{l}\text { Quadrado } \\
\text { da média }\end{array}$ & $F$ & Sig. \\
\hline \multirow{3}{*}{$\begin{array}{l}\text { Sinto-me como se as outras } \\
\text { crianças tivessem mais coisas } \\
\text { do que eu }\end{array}$} & Between Groups & 7.273 & 7.273 & 11.165 & .001 \\
\hline & Within Groups & 747.162 & .651 & & \\
\hline & Total & 754.435 & & & \\
\hline \multirow[t]{3}{*}{$\begin{array}{l}\text { Não me preocupo muito com o } \\
\text { que visto }\end{array}$} & Between Groups & .797 & .797 & .826 & .364 \\
\hline & Within Groups & 1107.789 & .966 & & \\
\hline & Total & 1108.587 & & & \\
\hline \multirow{3}{*}{$\begin{array}{l}\text { Gostaria que minha família } \\
\text { pudesse comprar mais daquilo } \\
\text { que desejo }\end{array}$} & Between Groups & 23.715 & 23.715 & 25.205 & .000 \\
\hline & $\begin{array}{l}\text { Within Groups } \\
\text { Total }\end{array}$ & 1079.209 & .941 & & \\
\hline & & 1102.924 & & & \\
\hline \multirow{3}{*}{$\begin{array}{l}\text { As marcas têm significado para } \\
\text { mim (me importo com as } \\
\text { marcas) }\end{array}$} & Between Groups & 20.794 & 20.794 & 19.730 & .000 \\
\hline & Within Groups & 1208.848 & 1.054 & & \\
\hline & Total & 1229.641 & & & \\
\hline \multirow{3}{*}{$\begin{array}{l}\text { Não me importo com o tipo de } \\
\text { carro que a minha família } \\
\text { possui. }\end{array}$} & Between Groups & 003 & 003 & 003 & \\
\hline & Within Groups & 1083.487 & .945 & & \\
\hline & Total & 1083.490 & & & \\
\hline \multirow[t]{3}{*}{$\begin{array}{l}\text { Tenho quase tudo de que } \\
\text { preciso em termos de posse }\end{array}$} & Between Groups & .006 & .006 & .008 & .928 \\
\hline & Within Groups & 826.271 & .720 & & \\
\hline & Total & 826.277 & & & \\
\hline \multirow[t]{3}{*}{$\begin{array}{l}\text { Sempre tenho algo em mente } \\
\text { que quero comprar ou conseguir }\end{array}$} & Between Groups & 10.834 & 10.834 & 15.490 & .000 \\
\hline & Within Groups & 802.252 & .699 & & \\
\hline & Total & 813.086 & & & \\
\hline \multirow{3}{*}{$\begin{array}{l}\text { Gostaria que meus pais me } \\
\text { dessem mais dinheiro para } \\
\text { gastar }\end{array}$} & Between Groups & 39.931 & 39.931 & 37.643 & .000 \\
\hline & Within Groups & 1216.712 & 1.061 & & \\
\hline & Total & 1256.642 & & & \\
\hline \multirow{3}{*}{$\begin{array}{l}\text { Quero ter muito dinheiro quando } \\
\text { crescer }\end{array}$} & Between Groups & 4.837 & 4.837 & 10.007 & .002 \\
\hline & Within Groups & 554.411 & .483 & & \\
\hline & Total & 559.248 & & & \\
\hline \multirow{3}{*}{$\begin{array}{l}\text { Preocupo-me muito com meus } \\
\text { brinquedos, jogos e outros } \\
\text { objetos }\end{array}$} & Between Groups & .717 & .717 & .954 & .329 \\
\hline & Within Groups & 862.150 & .752 & & \\
\hline & Total & 862.867 & & & \\
\hline \multirow[t]{3}{*}{ Gosto de comprar e ir às lojas } & Between Groups & 25.339 & 25.339 & 31.320 & .000 \\
\hline & Within Groups & 927.966 & .809 & & \\
\hline & Total & 953.305 & & & \\
\hline
\end{tabular}




\begin{tabular}{|c|c|c|c|c|c|}
\hline & & $\begin{array}{l}\text { Soma dos } \\
\text { quadrados }\end{array}$ & $\begin{array}{l}\text { Quadrado } \\
\text { da média }\end{array}$ & $\mathrm{F}$ & Sig. \\
\hline \multirow{3}{*}{$\begin{array}{l}\text { Gostaria que meus pais } \\
\text { ganhassem mais dinheiro }\end{array}$} & Between Groups & 102.039 & 102.039 & 117.730 & .000 \\
\hline & Within Groups & 994.125 & .867 & & \\
\hline & Total & 1096.164 & & & \\
\hline \multirow{4}{*}{$\begin{array}{l}\text { Quando escolho meus amigos, } \\
\text { não me preocupo com os } \\
\text { brinquedos ou objetos que eles } \\
\text { possuem }\end{array}$} & Between Groups & & & & \\
\hline & & 12.700 & 12.700 & 19.538 & .000 \\
\hline & Within Groups & 745.573 & .650 & & \\
\hline & Total & 758.273 & & & \\
\hline \multirow{3}{*}{$\begin{array}{l}\text { Gosto de roupas com etiquetas } \\
\text { reconhecidas (gosto de roupas } \\
\text { de marca) }\end{array}$} & Between Groups & 15.001 & 15.001 & 15.911 & .000 \\
\hline & Within Groups & 1081.361 & .943 & & \\
\hline & Total & 1096.362 & & & \\
\hline \multirow{3}{*}{$\begin{array}{l}\text { Quando vou a algum lugar } \\
\text { especial, normalmente compro } \\
\text { alguma coisa }\end{array}$} & Between Groups & 4.740 & 4.740 & 6.306 & .012 \\
\hline & Within Groups & 862.205 & .752 & & \\
\hline & Total & 866.945 & & & \\
\hline \multirow[t]{3}{*}{$\begin{array}{l}\text { Ser "cool" (maneiro, legal) é } \\
\text { importante para mim }\end{array}$} & Between Groups & 27.481 & 27.481 & 31.600 & .000 \\
\hline & Within Groups & 997.492 & .870 & & \\
\hline & Total & 1024.973 & & & \\
\hline
\end{tabular}




\section{CONCLUSÕES E RECOMENDAÇÕES}

Majoritariamente, a pesquisa foi respondida por crianças de 11 anos, brancas, que possuem os pais casados, moram junto com eles e esses responsáveis trabalham fora de casa. A grande diferença apontada pela pesquisa é a escolaridade dos pais, uma vez que os pais de crianças que estudam em escolas privadas possuem Ensino Superior completo e os pais de crianças que estudam em escolas públicas possuem Ensino Médio completo.

No que diz respeito às questões que mediam o envolvimento do consumidor infantil verificou-se que as crianças, independente da escola em que estudavam, são consumistas. Contudo, foi possível verificar por meio da ANOVA que as crianças que estudam em escolas públicas possuem um maior envolvimento do consumidor, comprovado em 10 dos 16 itens presentes no questionário.

O objetivo geral, que buscou comparar as diferenças entre o envolvimento do consumidor infantil em crianças de escolas públicas e privadas de Brasília foi alcançado, bem como os objetivos específicos, que estavam fundamentados em analisar o envolvimento do consumidor infantil em crianças de escolas públicas e privadas e traçar o perfil demográfico dos participantes.

$\mathrm{O}$ trabalho realizado possui algumas limitações. Em virtude do período em que a pesquisa foi feita, houve dificuldades em se obter a autorização das escolas para a aplicação dos questionários, pois com o final do semestre muitas escolas estavam em períodos de provas ou revisão para as provas e, portanto, não autorizaram a pesquisa. Além disso, uma greve de ônibus realizada no Distrito Federal no final do mês de junho atrapalhou a aplicação dos questionários nas escolas públicas, pois cerca da metade dos alunos não compareceram às aulas neste período, atrasando a coleta de dados. É importante ressaltar que a dificuldade em se obter a autorização das escolas também deveu-se à realização da Copa do Mundo de Futebol neste ano de 2010 nos meses de junho e julho, pois os jogos da seleção brasileira eram realizados sempre em horário matutino ou vespertino e as aulas nestes dias eram canceladas para os alunos, fazendo com que o tempo das escolas se tornasse ainda mais escasso. Havia também a urgência em se realizar a pesquisa o quanto antes, pois os alunos de escolas privadas entrariam de férias no dia 30 de junho e os de 
escola pública no dia 8 de julho, retomando as aulas somente no final de julho início de agosto, data próxima à entrega do trabalho.

O fato do questionário ter sido realizado no ambiente escolar possuiu prós e contras. Como pontos positivos, é possível citar que o ambiente escolar permitiu o fácil e rápido acesso à faixa etária estudada, uma vez que os alunos já estavam "separados" em idades pelas séries em que estudam. Além disso, foi possível aplicar um maior número de questionários em menor tempo, já que as crianças já estavam todas reunidas em virtude das aulas. Como ponto negativo deve-se ressaltar que como estavam em um ambiente conhecido, repleto de amigos, as crianças podem ter se deixado influenciar pela opinião dos colegas em algumas situações. Embora o questionário tenha sido preenchido individualmente, em alguns momentos as crianças respondiam as questões em voz alta e devido à proximidade das carteiras, por vezes elas "conferiam" as respostas dadas pelos amigos. Por se entender que esta é uma faixa etária que se importa de grande maneira com a opinião dos demais, alguns alunos podem ter levado em consideração as respostas dos demais colegas para responderem seus questionários.

Outra limitação desta pesquisa relaciona-se à sua natureza exclusivamente quantitativa. Em função do pouco tempo disponível para a pesquisa de campo pelos motivos já explicitados, não foi possível utilizar-se também da abordagem qualitativa, por meio de grupos focais, por exemplo. Acredita-se que uma pesquisa mista traria maiores esclarecimentos, principalmente com relação às questões que não puderam ser totalmente esclarecidas e relacionadas com a teoria encontrada.

O tamanho do questionário precisou ser bastante reduzido em virtude do pouco tempo concedido pelas escolas para aplicação da pesquisa, e esta redução pode ser enumerada como outra limitação deste estudo.

Como contribuição prática deste trabalho é possível citar o interesse manifestado por uma das escolas privadas pesquisadas em divulgar os resultados da pesquisa para seus alunos em virtude destas crianças estarem trabalhando no ano de 2010 com uma campanha relacionada ao consumismo e suas consequências. A escola acredita que as crianças poderão refletir sobre os resultados encontrados e conhecer um pouco melhor o comportamento dos colegas e amigos de classe. 
É possível citar como contribuições acadêmicas desta pesquisa a aplicação do questionário desenvolvido por Schor (2004), uma vez que não foram encontradas evidências de que este instrumento tenha sido utilizado anteriormente no Brasil, somente nos Estados Unidos e Reino Unido. Além disso, a pesquisa enriquece a produção de pesquisas na área de Marketing Infantil em âmbito nacional, um nicho que com o passar dos anos vem ganhando força e importância no país, mas que ainda tem um número de produções acadêmicas muito pequeno se comparado a outros setores do marketing.

Sugere-se que em estudos futuros sejam acrescentadas ao questionário questões referentes à exposição das crianças à mídia, principalmente televisiva, de maneira a observar a relação deste fator com o comportamento de consumo das crianças.

Outra sugestão é que seja realizada uma pesquisa mista, em virtude da riqueza de detalhes que o instrumento qualitativo aliado ao quantitativo tem a oferecer. Sugerese também a realização de entrevistas com os pais das crianças, de maneira a se obter informações mais precisas sobre a renda familiar, possibilitando uma classificação mais acurada dos níveis socioeconômicos das crianças, além da entrevista possibilitar captar a percepção dos pais com relação ao consumismo dos filhos. 


\section{REFERÊNCIAS}

ACHENREINER, G. B.; JOHN, D. R. The meaning of brand names to children: a developmental investigation. Journal of Consumer Psychology, v.13, n.3, p. 205219, 2003.

BARBETTA, P. A. Testes estatísticos de hipóteses. In: Estatística aplicada às ciências sociais. 5. ed. Florianópolis: Editora da UFSC, 2005. cap.10

BOTTOMLEY ET AL. Measuring Childhood materialism: validating and refining Schor's consumer involvement scale. 2007.

BRASIL. Lei no 9.394, de 20 de dezembro de 1996. Estabelece as Diretrizes e Bases da Educação Nacional. Diário Oficial [da] República Federativa do Brasil, Brasília, DF, v. 134, n. 248, 23 dez. 1996.

BUIJZEN, M.; VALKENBURG, P. M. The effects of television advertising on materialism, parent-child conflict, and unhappiness: a review of research. Applied Developmental Psychology. n. 24, p. 437-456, 2003.

CALVERT, S. L. Children as consumers: advertising and marketing. The future of children, v.18, n.1, p. 205-234, 2008.

CHILDS, N. M.; MAHER, J. K. Gender in food advertising to children: boys eat first. British Food Journal. v. 105, n.7, p. 408-419, 2003.

CECCARELLI, P. R. Televisão, mídia e seus efeitos perversos. In: COMPARATO, C.; MONTEIRO, D. (Org.). A criança na contemporaneidade e a psicanálise. Mentes e mídia: diálogos interdisciplinares. São Paulo: Casa do Psicólogo, 2000, v. 02, p. 75-86.

COBRA, M. Administração de marketing orientada para o mercado. In: Administração de marketing. 2. ed. São Paulo: Atlas, 1992a. cap. 1.

A segmentação estratégica de mercados. In:

Administração de marketing. 2. ed. São Paulo: Atlas, 1992b. cap. 9. 
FACCI, Marilda Gonçalves Dias. A periodização do desenvolvimento psicológico individual na perspectiva de Leontiev, Elkonin e Vigostski. Cad. CEDES [online], v.24, n.62, pp. 64-81, 2004.

GROSSI, P. K.; SANTOS, A. M. Infância comprada: hábitos de consumo na sociedade contemporânea. Revista Textos \& Contextos, v.6, n.2, p. 443-454, 2007.

HARTUP, W. W. Having friends, making friends, and keeping friends: relationships as educational contexts. ERIC Digest [online], 1992. Disponível em:

<http://ericeece.org/pubs/digests/1992/hartup92.html > Acesso em: 31 jul. 2010

INEP. Censo Escolar 2009. Disponível em:

$<$ http://www.inep.gov.br/imprensa/noticias/censo/escolar/news09_11.htm>. Acesso em: 15 jun. 2010

Kids Power, TNS Inter Science, 2007. Disponível em:

<http://www.interscience.com.br/site2006/download/estudosInstitucionais/KIDSPOW ER.pdf >. Acesso em 24 jul. 2010.

KOTLER, P.; KELLER, K. L. Marketing para o século XXI. In:

Administração de Marketing. 12. ed. São Paulo: Pearson Prentice Hall, $2006 a$. cap. 1.

Análise dos mercados consumidores. In: Administração de Marketing. 12. ed. São Paulo: Pearson Prentice Hall, 2006b. cap. 6.

. Identificação de segmentos de mercado e seleção de mercados-alvo.

In:_ Administração de Marketing. 12. ed. São Paulo: Pearson Prentice Hall, 2006c. cap. 8.

LAS CASAS, A. L. Segmentação. In: casos. 4. ed. São Paulo: Atlas, 1997. cap.4.

Marketing: conceitos, exercícios,

LAURINDO, R.; LEAL, A. A recepção da publicidade na TV entre crianças de cinco anos. Comunicação, mídia e consumo, v.5, n.13, p. 139-157, 2008.

LINN, S. Crianças do Consumo: a infância roubada. São Paulo: Instituto Alana, 2006. 
MARCONDES FILHO, C. Os gêneros da TV. In: vídeo. São Paulo: Moderna, 1988. cap. 3.

Televisão: a vida pelo

MAYO, E. Shopping Generation. National Consumer Council, 2005. Disponível em: <http://www.aeforum.org/aeforum.nsf/6598c891ee95a16a80256c5100355eb0/454e9 00c39c957418025703b004108ed/\$FILE/shopping_generation.pdf> Acesso em 24 jul. 2010.

MCDOUGALLI, J.; CHANTREY D. The making of tomorrow's consumer. Young Consumers, v. 5, n. 4, p. 8-18, 2004.

McNEAL, J. U. Children as consumers: a review. Journal of the Academy of Marketing Science, v.7, n.4, p. 346-359, 1979. 1998.

. Tapping the three kids' markets. American Demographics. p. 37-41. abr.

O'SULLIVAN, T. Advertising and children: what do the kids think? Qualitative Market Research: An International Journal, v.8, n.4, p. 371-384, 2005.

PAGE, C.; RIDGWAY, N. The impact of consumer environments on consumption patterns of children from disparate socioeconomic backgrounds. Journal of Consumer Marketing, v.18, n.1, p.21-40, 2001.

PAINE,W. S.; STEWART K. L.; KRUGER, E. J. Preventing Ethical Problems when Marketing to minors. Advertising \& Marketing to Children, v.3, n.2, p. $69-80$, jan/mar. 2002.

PINHO, J. B. Conceitos centrais do marketing moderno. In: Comunicação em Marketing. 5. ed. Campinas: Papirus, 2001. Cap.1.

REZENDE, A. L. M.; REZENDE, N. B. Sob o signo da Tevê. In: A tevê e a criança que te vê. 2. ed. São Paulo: Cortez, 1993. cap. 1.

RICHERS, R. Marketing: um desafio nacional. In: brasileira. São Paulo: Negócio Editora, 2000. cap. 1. Marketing: uma visão 
ROBERTS, J. A.; MANOLIS, C. Baby boomers and busters: an exploratory investigation of attitudes toward marketing, advertising and consumerism. Journal of Consumer Marketing, v. 17, n.6, p. 481-499, 2000.

ROCHA, A.; CHRISTENSEN. O Mercado. In: Marketing: teoria e prática no Brasil. São Paulo: Atlas, 1987. cap. 2.

ROSS, J.; HARRADINE R. I'm not wearing that! Branding and young children. Journal of Fashion Marketing and Management. v.8, n.1, p. 11-26, 2004.

SAMPAIO, I. S. V. Televisão, publicidade e infância. São Paulo: Annablume, 2000.

SCHOR, J. B. Nascidos para Comprar. São Paulo: Editora Gente, 2004.

SHOHAM, A.; DALAKAS, V. He said, she said... they said: parent's and children's assessment of children's influence on family consumption decisions. Journal of Consumer Marketing, v.22, n.3, p. 152-160, 2005.

SILVA, D, R.; AVANZI, A. P.; SILVA, G. P. C. A influência do público infantil no processo de compra de pacotes turísticos. In: CONGRESSO BRASILEIRO DE CIÊNCIAS DA COMUNICAÇÃO, 30, 2007, Santos. Anais...Santos, 2007.

SOARES, J. F.; ALVES, M. T. G. Desigualdades raciais no sistema brasileiro de educação básica. Educação e Pesquisa, v.29, n.1, p. 147-165, 2003.

STEVENSON, W. J. Análise de Variância. In: Administração. São Paulo: Harbra, 1997. cap. 11. Estatística Aplicada à

Administraça. Săo Paulo: Harbra, 1997. cap. 11.

STORY, M. FRENCH, S. Food advertising and marketing directed at children and adolescents in the US. Internacional Journal of Behavioral Nutrition and Physical Activity, fev. 2004. Disponível em: <http://www.ijbnpa.org/content/1/1/3>. Acesso em: 20 mar. 2010.

STRASBURGER, V. C. Children, adolescents, and the media. Current Problems in Pediatric and Adolescent health care, n.34, p. 54-113, fev. 2004. 
VALKENBURG, P. M. Media and youth consumerism. Journal of Adolescent Health, v.27S, n.2, p.52-56, 2000.

VALKENBURG, P. M.; CANTOR, J. The development of a child into a consumer. Applied Developmental Psychology, n.22, p.61-71, 2001.

VERGARA, S. C. Começando a definir a metodologia. In: Projetos e relatórios de pesquisa em Administração. 3. ed. São Paulo: Atlas, 2000. cap.4. 


\section{APÊNDICE A}

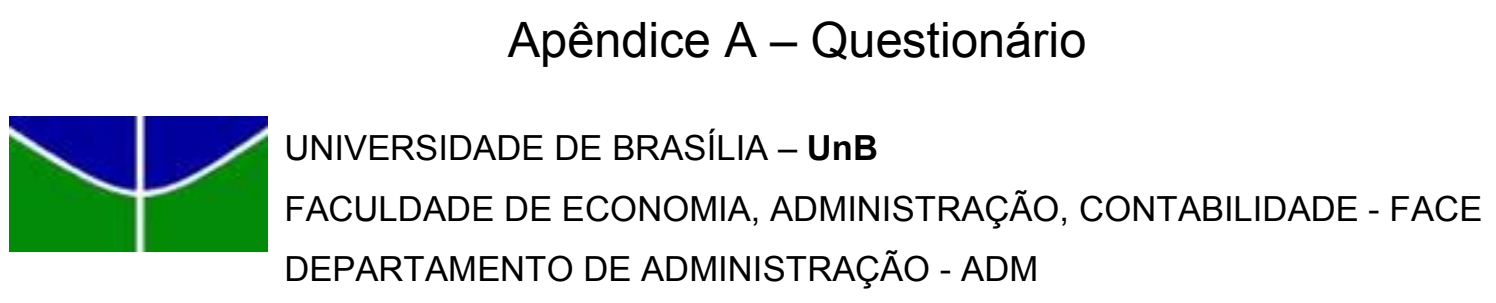

Questionário: "Pesquisa sobre o envolvimento do consumidor infantil"

Prezado estudante, esta é uma pesquisa de caráter acadêmico. Gostaríamos de contar com a sua colaboração para responder ao questionário abaixo. Não existem respostas certas ou erradas. O importante é você responder as questões honestamente. O propósito desta pesquisa é aprender mais sobre o consumidor infantil.

I. Perguntas sobre você e sua família, marque somente uma alternativa.

1. Quantos anos você tem?
a. $9 \operatorname{anos}($ )
b. 10 anos ( )
c. 11 anos ( )
d.12 anos ( )

2. Você é...
a. menino
b. menina ( )

3. Qual a sua raça ou etnia?
a. branco ( )
b. negro ( )
c. asiático ( )
d. índio ( )
e. outro ( )

4. Qual a escolaridade da sua mãe?
a. ensino fundamental incompleto ( )
b. ensino fundamental completo ( )
c. ensino médio incompleto ( )
d. ensino médio completo ( )
e. ensino superior incompleto ( )
f. ensino superior completo ( )

5. Qual a escolaridade do seu pai?
a. ensino fundamental incompleto ( )
b. ensino fundamental completo ( )
c. ensino médio incompleto ( )
d. ensino médio completo ( )
e. ensino superior incompleto ( )
f. ensino superior completo ( ) 
6. Você mora com a sua mãe?

a. $\operatorname{sim}($ ) b. não ( )

7. Você mora com seu pai?

a. $\operatorname{sim}($ ) b. não ( )

8. Os seus pais são:

a. casados ( ) b. divorciados ( ) c. nunca casaram ( ) d. viúvos ( ) e. outros ( )

9. A sua mãe trabalha?

a. $\operatorname{sim}($ ) b. não ( )

10. O seu pai trabalha?

a. $\operatorname{sim}($ ) b. não ( )

II. Para cada afirmação, escolha UMA resposta que descreva melhor como você se sente. Não existem respostas certas ou erradas.

\begin{tabular}{|l|l|l|l|l|}
\hline \multicolumn{1}{|c|}{ Afirmação } & $\begin{array}{c}\text { Concordo } \\
\text { fortemente }\end{array}$ & Concordo & Discordo & $\begin{array}{c}\text { Discordo } \\
\text { fortemente }\end{array}$ \\
\hline $\begin{array}{l}\text { 1- Sinto-me como se as } \\
\text { outras crianças tivessem } \\
\text { mais coisas do que eu. }\end{array}$ & & & & \\
\hline $\begin{array}{l}\text { 2- Não me preocupo muito } \\
\text { com o que visto. }\end{array}$ & & & & \\
\hline $\begin{array}{l}\text { 3- Gostaria que minha } \\
\text { família pudesse comprar } \\
\text { mais daquilo que desejo. }\end{array}$ & & & & \\
\hline $\begin{array}{l}\text { 4- As marcas têm significado } \\
\text { pra mim (me importo com as } \\
\text { marcas). }\end{array}$ & & & & \\
\hline $\begin{array}{l}\text { 5- Não me importo com o } \\
\text { tipo de carro que a minha } \\
\text { familia possui. }\end{array}$ & & & & \\
\hline $\begin{array}{l}\text { 6- Tenho quase tudo de que } \\
\text { preciso em termos de posse. }\end{array}$ & & & & \\
\hline $\begin{array}{l}\text { 7- Sempre tenho algo em } \\
\text { mente que quero comprar ou } \\
\text { conseguir. }\end{array}$ & & & & \\
\hline
\end{tabular}




\begin{tabular}{|l|l|l|l|l|}
\hline \multicolumn{1}{|c|}{ Afirmação } & $\begin{array}{c}\text { Concordo } \\
\text { fortemente }\end{array}$ & Concordo & Discordo & $\begin{array}{c}\text { Discordo } \\
\text { fortemente }\end{array}$ \\
\hline $\begin{array}{l}\text { 8- Gostaria que meus pais } \\
\text { me dessem mais dinheiro } \\
\text { para gastar. }\end{array}$ & & & & \\
\hline $\begin{array}{l}\text { 9- Quero ter muito dinheiro } \\
\text { quando crescer. }\end{array}$ & & & \\
\hline $\begin{array}{l}\text { 10- Preocupo-me muito com } \\
\text { meus brinquedos, jogos e } \\
\text { outros objetos. }\end{array}$ & & & \\
\hline $\begin{array}{l}\text { 11- Gosto de comprar e ir às } \\
\text { lojas. }\end{array}$ & & & \\
\hline $\begin{array}{l}\text { 12- Gostaria que meus pais } \\
\text { ganhassem mais dinheiro. }\end{array}$ & & & \\
\hline $\begin{array}{l}\text { 13- Quando escolho meus } \\
\text { amigos, não me preocupo } \\
\text { com os brinquedos ou } \\
\text { objetos que eles possuem. }\end{array}$ & & & & \\
\hline $\begin{array}{l}\text { 14- Gosto de roupas com } \\
\text { etiquetas reconhecidas } \\
\text { (Gosto de roupas de marca). }\end{array}$ & & & & \\
\hline $\begin{array}{l}\text { 15- Quando vou a algum } \\
\text { lugar especial, normalmente } \\
\text { compro alguma coisa. }\end{array}$ & & & & \\
\hline $\begin{array}{l}\text { 16- Ser "cool" (maneiro, } \\
\text { legal) é importante para mim. }\end{array}$ & & & & \\
\hline
\end{tabular}

